\title{
On instrumental errors and related correction strategies of ozonesondes: possible effect on calculated ozone trends for the nearby sites Uccle and De Bilt
}

\author{
Roeland Van Malderen ${ }^{1}$, Marc A. F. Allaart ${ }^{2}$, Hugo De Backer ${ }^{1}$, Herman G. J. Smit ${ }^{3}$, and Dirk De Muer ${ }^{1}$ \\ ${ }^{1}$ Royal Meteorological Institute of Belgium, Ringlaan 3, 1180 Uccle (Brussels), Belgium \\ ${ }^{2}$ Royal Netherlands Meteorological Institute, P.O. Box 201, 3730 AE De Bilt, the Netherlands \\ ${ }^{3}$ Forschungszentrum Jülich GmbH, Institut für Energie and Klimaforschung, IEK-8 Troposphäre, 52425 Jülich, Germany \\ Correspondence to: Roeland Van Malderen (roeland.vanmalderen@meteo.be)
}

Received: 6 November 2015 - Published in Atmos. Meas. Tech. Discuss.: 18 January 2016

Revised: 25 July 2016 - Accepted: 1 August 2016 - Published: 18 August 2016

\begin{abstract}
The ozonesonde stations at Uccle (Belgium) and De Bilt (the Netherlands) are separated by only $175 \mathrm{~km}$ but use different ozonesonde types (or different manufacturers for the same electrochemical concentration cell (ECC) type), operating procedures, and correction strategies. As such, these stations form a unique test bed for the Ozonesonde Data Quality Assessment (O3S-DQA) activity, which aims at providing a revised, homogeneous, consistent dataset with an altitude-dependent estimated uncertainty for each revised profile. For the ECC ozonesondes at Uccle mean relative uncertainties in the 4-6\% range are obtained. To study the impact of the corrections on the ozone profiles and trends, we compared the Uccle and De Bilt average ozone profiles and vertical ozone trends, calculated from the operational corrections at both stations and the O3S-DQA corrected profiles.

In the common ECC 1997-2014 period, the O3S-DQA corrections effectively reduce the differences between the Uccle and De Bilt ozone partial pressure values with respect to the operational corrections only for the stratospheric layers below the ozone maximum. The upper-stratospheric ozone measurements at both sites are substantially different, regardless of the correction methodology used. The origin of this difference is not clear. The discrepancies in the tropospheric ozone concentrations between both sites can be ascribed to the problematic background measurement and correction at De Bilt, especially in the period before November 1998. The Uccle operational correction method, applicable to both ozonesonde types used, diminishes the relative stratospheric ozone differences of the Brewer-Mast sondes in the
\end{abstract}

1993-1996 period with De Bilt to less than 5\% and to less than $6 \%$ in the free troposphere for the De Bilt operational corrections.

Despite their large impact on the average ozone profiles, the different (sensible) correction strategies do not change the ozone trends significantly, usually only within their statistical uncertainty due to atmospheric noise. The O3S-DQA corrections bring the Uccle and De Bilt ozone trend estimates for 1997-2014 closer to each other in the lower stratosphere and lower troposphere. Throughout the whole vertical profile, these trend estimates are, however, not significantly different from each other, and only in the troposphere significantly positive. For the entire Uccle observation period (1969-2014), the operational corrections lead to height-independent and consistent ozone trends for both the troposphere and the stratosphere, with rates of +2 to $+3 \%$ decade $^{-1}$ and -1 to $-2 \%$ decade $^{-1}$, respectively.

\section{Introduction}

Although it is a minor constituent, ozone is present throughout the whole lower atmosphere. Depending on the location in the atmosphere, the molecule is involved in different chemical reactions and therefore has a different impact on life on Earth. For instance, ozone absorbs both infrared and ultraviolet (UV) radiation, but the former reaction is more dominant in the tropopause region, where ozone acts as a greenhouse gas with an estimated globally averaged radiative 


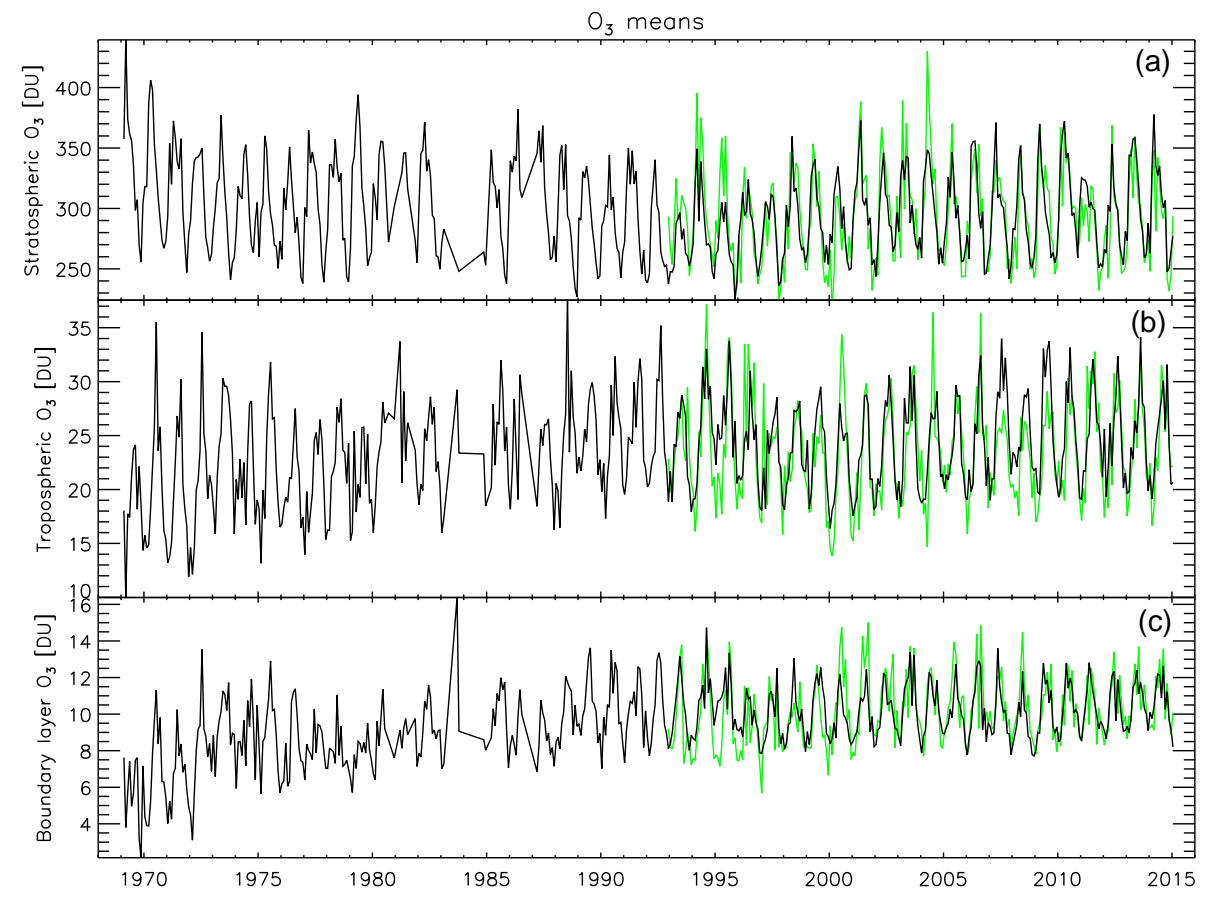

Figure 1. Time series of monthly means of integrated ozone amounts in Dobson units (DU) above Uccle (black) and De Bilt (green) for different parts in the atmosphere: (a) stratosphere ( $h>$ tropopause height), (b) free troposphere $(3 \mathrm{~km}<h<$ tropopause height), and (c) boundary layer $(0-3 \mathrm{~km})$.

forcing of $0.40 \pm 0.20 \mathrm{Wm}^{-2}$ (IPCC, 2013). In contrast, the higher ozone amounts in the stratosphere effectively block the harming solar UV radiation and act as a UV-filter for the living beings on earth. At the surface, ozone is an air pollutant that adversely impacts human health, natural vegetation, and crop yield and quality (e.g. Cooper et al., 2014).

Since ozone at different (vertical) atmospheric layers is formed and destroyed by different photochemical reactions and with precursor emissions from both natural and anthropogenic sources - the time variability of the ozone abundance (on seasonal, interannual, and decadal timescales) highly depends on the location (height) of ozone molecules in the atmosphere. This is illustrated in Fig. 1, in which stratospheric, tropospheric, and boundary layer ozone monthly means are shown for the period 1969-2014 for the Uccle (Brussels, Belgium) station and for the period 1993-2014 for De Bilt (the Netherlands). The significant decrease of stratospheric ozone in Uccle over the 1969-2014 period (see also Fig. 10) can be ascribed to the growth of the man-made emissions of ozone-depleting substances (ODSs; chlorofluorocarbon is a typical example) until the late 1980s. Thanks to the regulation of these ODSs in the Montreal Protocol (1987), the stratospheric ozone concentrations stopped decreasing during the late 1990s and should recover in the next decades (Newman et al., 2009; WMO, 2014). Tropospheric and especially boundary layer ozone concentrations increased significantly since 1969; see Fig. 10. This increase is caused by growing emissions of, for example, nitrogen oxides $\left(\mathrm{NO}_{x}\right)$, methane, carbon monoxide and hydrocarbons particularly in the first (2) decades (e.g. Logan et al., 2012). Thereafter, a levelling off of the ozone amounts took place due to declining anthropogenic ozone precursor emissions (e.g. Cooper et al., 2014).

The observations used in Fig. 1 to construct the integrated ozone amount time series are gathered with ozonesondes, lightweight instruments attached to weather balloons and electronically coupled with a standard meteorological radiosonde for data transmission to a ground receiver. Ozonesondes provide the vertical distribution of ozone at very high vertical resolution (typically a few $100 \mathrm{~m}$ ), up to altitudes in the range of $30-35 \mathrm{~km}$. They have been launched worldwide for already more than half a century and therefore constitute the most important data source to derive long-term ozone trends with sufficient vertical resolution up to about $20 \mathrm{~km}$ (SPARC-IOC-GAW, 1998). A major concern for any research with ozonesonde measurements is the data homogeneity and consistency because every profile is obtained with a unique instrument and different types of ozonesondes exist. Consequently, every ozonesonde needs to be prepared and checked thoroughly prior to launch. To have consistency between different ozonesonde stations, it is essential to have agreement on procedures for preparation as well as agreement on procedures for data processing and analysis (Smit and the Panel for ASOPOS, 2011). Therefore, within 
the $\mathrm{SI}^{2} \mathrm{~N}$ Initiative ${ }^{1}$ on "Past Changes in the Vertical Distribution of Ozone" (Harris et al., 2011), the Ozonesonde Data Quality Assessment (O3S-DQA) has been initiated with the aim to provide a revised, homogeneous dataset with corrections applied for biases related to instrumental changes (such as sonde type or electrolyte solution) in those cases where comparisons or laboratory experiments provide strong evidence for such corrections (Harris et al., 2012). This exercise should result in an improved ozonesonde record with a reduced uncertainty (from 10-20\% down to 5-10\%), giving more solid information about the atmospheric changes that have occurred, as well as a better dataset for comparison with satellite measurements. The Canadian ozonesonde record has recently been re-evaluated regarding the O3S-DQA principles and the results are presented in Tarasick et al. (2016).

In this paper, for the two nearby sites Uccle (Belgium) and De Bilt (the Netherlands), ozonesonde data processed by the principles of O3S-DQA are presented for the first time. However, both stations also developed their own data correction algorithms. Both sites are separated only $175 \mathrm{~km}$ from each other. The typical horizontal ozone correlation length is about $500 \mathrm{~km}$ in the troposphere (Liu et al., 2013) and $1500 \mathrm{~km}$ in the stratosphere (Liu et al., 2009). Timescales of autocorrelation vary between about 1.5 and 3.5 days in the troposphere and between 2 and 6 days in the stratosphere (Liu et al., 2009). Therefore, Uccle and De Bilt have a similar vertical distribution of ozone (see Van Malderen et al., 2014, and Fig. 1), with similar average annual cycles for especially stratospheric and free tropospheric ozone (see Fig. 2), although geophysical differences between the two sites cannot completely ruled out. As a consequence, these data should enable us to investigate the impact of different correction strategies on the vertical ozone profiles and the derived trends. This research is a follow-up study of Van Malderen et al. (2014), in which the comparison of the ozonesonde data of both stations was used to identify the origin of anomalous high tropospheric ozone in the Uccle data during a 2.5-year period (beginning of 2007 to mid-2009). Moreover, this study is an update of De Backer et al. (1996), who already reported on differences between profiles obtained at Uccle and De Bilt with different types of ozonesondes in the early years of the De Bilt time series.

This paper is organised as follows: in the next section, we will describe the data, pre-flight preparations, and post-flight data processing at the two sites. An uncertainty assessment of the ozone profile data is also provided. In Sect. 3 we assess the impact of these different post-flight data processing steps

\footnotetext{
${ }^{1}$ This is a joint initiative under the auspices of SPARC (Stratosphere-troposphere Processes And their Role in Climate), the International Ozone Commission $\left(\mathrm{IO}_{3} \mathrm{C}\right)$, the ozone focus area of the Integrated Global Atmospheric Chemistry Observations (IGACO-O $)_{3}$ ) programme, and the Network for Detection of Atmospheric Composition Change (NDACC). For simplicity, an acronym of acronyms, $\mathrm{SI}^{2} \mathrm{~N}$, was adopted.
}

and methods on the average profiles of both sites. For different time periods, the vertical trends at Uccle and De Bilt are calculated and compared. The impact of the data handling procedures on these trends is analysed in Sect. 4. The last Sect. 5 presents the conclusions of our study.

\section{Data}

Since the 1960s, three main types of electrochemical ozonesondes are in use: the Brewer-Mast (BM, Brewer and Milford, 1960), the electrochemical concentration cell (ECC; Komhyr, 1969), and the Japanese carbon iodine cell (KC; Kobayashi and Toyama, 1966). At present, most sites use ECC sondes. ECC sondes are manufactured either by Science Pump Corporation (SPC; model types 5A and 6A), or, since the early nineties, by the Environmental Science Corporation (ENSCI; model type Z). In 2011 ENSCI was taken over by Droplet Measurement Technologies (DMT). These two types of ECC sondes only have minor differences in construction and differences in recommended sensing solution strength (SST) and of its phosphate buffer (Smit et al., 2007; Deshler et al., 2008). For the BM and the ECC sondes, the principle of operation is based on the chemical titration of $\mathrm{O}_{3}$ in a potassium iodide (KI) sensing solution. For each molecule of $\mathrm{O}_{3}$ entering the solution in the cell with the help of a very stable miniature piston pump, two iodide ions $\left(\mathrm{I}^{-}\right)$are oxidised to form iodine $\left(\mathrm{I}_{2}\right)$, which is subsequently reduced back to $\mathrm{I}^{-}$at the electrodes, generating an electric current of two electrons. This current can directly be related to the number of moles of ozone, sampled per second and cubic centimetres, by the formula (Smit and the Panel for ASOPOS, 2011)

$n_{\mathrm{O}_{3}}=\frac{\left(I_{\mathrm{M}}-I_{\mathrm{B}}\right)}{\left(\eta_{\mathrm{c}} \cdot 2 \cdot F \cdot \Phi_{\mathrm{p}}\right)}$,

where $I_{\mathrm{M}}$ and $I_{\mathrm{B}}$ are the measured electric cell current and background current (both in $\mu \mathrm{A}$ ), respectively, $\eta_{\mathrm{c}}$ is the conversion efficiency, F is Faraday's constant $(=9.6487 \times$ $10^{4} \mathrm{C}$ mole ${ }^{-1}$ ), and $\Phi_{\mathrm{p}}$ is the pump flow rate in $\mathrm{cm}^{3} \mathrm{~s}^{-1}$. The conversion efficiency is determined by the absorption efficiency $\alpha_{\mathrm{O}_{3}}$ of $\mathrm{O}_{3}$ into the sensing solution and the stoichiometry $\mathrm{S}_{\mathrm{O}_{3} / \mathrm{I}_{2}}$ of the conversion of $\mathrm{O}_{3}$ into $\mathrm{I}_{2}$. The factor 2 in the denominator points to the number of electrons produced in the sensor cell per ozone molecule. The pump flow rate $\Phi_{\mathrm{p}}$ and the background current $I_{\mathrm{B}}$ are measured prior to launch. By applying the ideal gas law the corresponding partial pressure of ozone can be expressed as

$P_{\mathrm{O}_{3}}=n_{\mathrm{O}_{3}} \cdot R \cdot T_{\mathrm{p}}=0.043085 \cdot \frac{T_{\mathrm{p}}}{\left(\eta_{\mathrm{c}} \cdot \Phi_{\mathrm{p}}\right)} \cdot\left(I_{\mathrm{M}}-I_{\mathrm{B}}\right)$

where $T_{\mathrm{p}}$ is the measured pump temperature $(\mathrm{K})$ and $\mathrm{R}$ is the universal gas constant $\left(=8.314 \mathrm{~J} \mathrm{~K}^{-1}\right.$ mole $\left.^{-1}\right)$.

Uncertainties may change during flight as the pump efficiency degrades with increasing altitude or due to inaccurate 


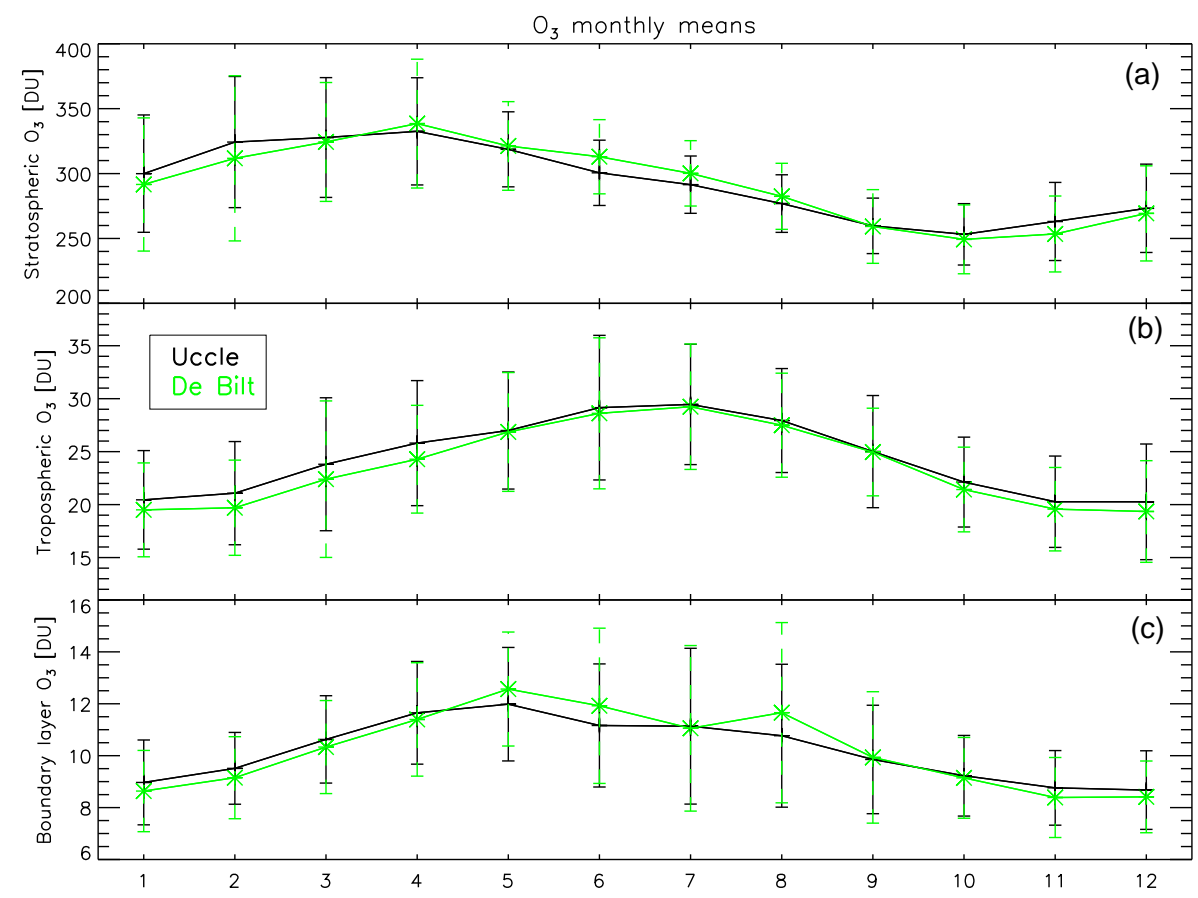

Figure 2. The average annual cycle for the period 1993-2014 of integrated ozone amounts above Uccle (black) and De Bilt (green) for different parts in the atmosphere: (a) stratosphere ( $h>$ tropopause height), (b) free troposphere $(3 \mathrm{~km}<h<$ tropopause height), and (c) boundary layer $(0-3 \mathrm{~km})$. Vertical error bars denote the $1 \sigma$ standard deviations around the monthly mean, calculated from the integrated ozone amounts of all individual ozone profiles.

pump temperature measurements or the presence of a background current that is subtracted from the measured current (Staufer et al., 2014, and references therein). Within the O3SDQA initiative, an uncertainty analysis has been developed and the overall relative uncertainty of $P_{\mathrm{O}_{3}}$ is expressed as a composite of the contributions of the individual uncertainties of the different listed instrumental parameters above (Smit and the Panel for ASOPOS, 2011):

$\frac{\Delta P_{\mathrm{O}_{3}}}{P_{\mathrm{O}_{3}}}=$

$\sqrt{\frac{\left(\Delta I_{\mathrm{M}}\right)^{2}+\left(\Delta I_{\mathrm{B}}\right)^{2}}{\left(I_{\mathrm{M}}-I_{\mathrm{B}}\right)^{2}}+\left(\frac{\Delta \eta_{\mathrm{c}}}{\eta_{\mathrm{c}}}\right)^{2}+\left(\frac{\Delta \Phi_{\mathrm{p}}}{\Phi_{\mathrm{p}}}\right)^{2}+\left(\frac{\Delta T_{\mathrm{p}}}{T_{\mathrm{p}}}\right)^{2}}$.

As some of the contributions depend on the air pressure, the overall uncertainty of the ozone measurement is a function of pressure or altitude. The O3S-DQA initiative therefore provides this uncertainty estimate for each ozone measurement of the vertical profile. It should be noted that this uncertainty estimation does not take into account the uncertainty due to the time lag of the response of the $I_{\mathrm{M}}, T_{\mathrm{p}}$ and even $I_{\mathrm{B}}$ measurements. However, for trends, this effect is of minor importance since these time lags do not change much over time. For the ECC ozonesondes at Uccle, the average profiles of the relative uncertainties and the contributions from the individual uncertainties of the different instrumental parameters as defined in Eq. (3) are shown in Fig. 3.
At Uccle, the overall uncertainty in the stratosphere is between 4 and $5 \%$, while in the troposphere it varies between 5 and $6 \%$. Overall, the conversion efficiency is the predominant uncertainty at Uccle $(\approx 3.6 \%$ or the square root of the sum of the squares of the relative uncertainties of the absorption efficiency $\alpha_{\mathrm{O}_{3}}$ and the stoichiometry $\mathrm{S}_{\mathrm{O}_{3} / \mathrm{I}_{2}}$, which are, respectively, 0.02 and 0.03,; see Smit et al., 2012), and the background current (BGC) has the largest influence on the overall uncertainty at the lowest $\mathrm{O}_{3}$ concentrations in the upper troposphere. Unfortunately, the physicochemical origin of the BGC is not well understood and further research is required to better understand its origin and its appropriate measurement and treatment (Smit et al., 2007; Vömel and Diaz, 2010; Smit and the Panel for ASOPOS, 2011). The pump efficiency uncertainty contributes significantly to the overall uncertainty at altitudes starting from the ozone maximum, which, in altitudes relative to the tropopause, is in Uccle, located around $10-15 \mathrm{~km}$ (Fig. 3). The average altitude of the tropopause at Uccle is about $11 \mathrm{~km}$.

The relative uncertainties of BM sondes are even harder to estimate, and the accuracy limitations appear to come from manufacturing aspects (material used, specifications, provider, etc.) as well as from details of the preparation procedures (Stuibi et al., 2008). Therefore, the results from previous comparisons of BM sondes with other types of sondes, either on dual flights or in the laboratory, or with other instrument types are not consistent (Smit and Kley, 1998; Stübi 




Figure 3. Relative uncertainty of the ozone partial pressure and the contributions from the individual uncertainties of the different instrumental parameters like measured cell current $I_{\mathrm{M}}$, background current $I_{\mathrm{B}}$, conversion efficiency $\eta_{\mathrm{c}}$, pump flow rate $\Phi_{\mathrm{p}}$, and pump temperature $T_{\mathrm{P}}$ as a function of altitude relative to the tropopause. These vertical profiles are the average profiles of these uncertainties, calculated for all $\mathrm{ECC} \mathrm{O}_{3}$ profiles at Uccle. The black dashed line is the mean $\mathrm{O}_{3}$ profile at Uccle, in units of $\mathrm{mPa}$ (see upper scale), for the same period (1997-2014). This figure has been adapted from Fig. 3-1 in Smit and the Panel for ASOPOS (2011) for the Uccle case.

et al., 2008). The performance of the BM sondes in the troposphere is even more problematic than in the stratosphere, and the quality of tropospheric data from earlier European BM sondes has been questioned by Schnadt Poberaj et al. (2009) and Logan et al. (2012). The BM sondes flown operationally at Hohenpeissenberg, Payerne, and Uccle from 1994 to 1997 overestimate $\mathrm{O}_{3}$ by up to $25 \%$ in the upper troposphere compared to the MOZAIC aircraft measurements (Staufer et al., 2014).

\subsection{Metadata}

The ozonesonde stations of Uccle $\left(50^{\circ} 48^{\prime} \mathrm{N}, 4^{\circ} 21^{\prime} \mathrm{E}\right.$; $100 \mathrm{~m}$ a.s.l.) and De Bilt $\left(52^{\circ} 10^{\prime} \mathrm{N}, 5^{\circ} 18^{\prime} \mathrm{E}\right.$; $4 \mathrm{~m}$ a.s.l. $)$ are located only about $175 \mathrm{~km}$ from each other, in urbanised environments. Uccle is in the southern, residential area of Brussels (about 1 million inhabitants). It is classified as a suburban station, according to European standards (2008/50/EC, 2008). De Bilt is to the east of Utrecht (about 300000 inhabitants) and about $50 \mathrm{~km}$ to the south of Amsterdam, the capital of the Netherlands. The ozonesonde program in Uccle started in January 1969 and makes up, together with Payerne and Hohenpeissenberg, the three longest time series in Europe. In the 1980s there were some minor interruptions. The launch frequency is three times a week (on Monday, Wednesday, and Friday). The De Bilt ozonesonde time series dates back to November 1992, and measurements are made weekly, preferentially on Thursday (or Tuesday, but not on the same day as Uccle).

In Table 1, an overview of the ozonesonde properties of both stations is given. At Uccle, two types of ozonesondes have been used: in April 1997, the BM sondes were operationally replaced with Model-Z ENSCI ECC sondes. However, during the period October 1996-December 1997, both types were launched interchangeably, either on double soundings (34 pairs; see De Backer et al., 1998a) or individually. The De Bilt time series is built up with a single ozonesonde type, SPC ECC, hereby two model types have been used during the record: SPC 5A and 6A. The latter is in use since 24 July 1997, but with an interception of more than 1 year (30 September 1999-1 March 2001), when the SPC $5 \mathrm{~A}$ has been launched again. Both stations used the same radiosonde types during their overlap period (Vaisala's RS80 and RS92), but the switch was made at different dates; see Table 1. Before 1990, VIZ radiosondes were launched at Uccle. Although both ozonesonde stations used different ECC ozonesonde types, they both consistently stuck to the manufacturer's recommended SSTs, $0.5 \%$ and $1 \% \mathrm{KI}$ for ENSCI $\mathrm{Z}$ (Uccle) and SPC (De Bilt), respectively. Therefore, the response of both ozonesondes should be very similar, as assessed in an environmental simulation chamber (Smit et al., 2007) and on a balloon experiment (Deshler et al., 2008). It should, however, be noted that the amount of the sensing so- 
Table 1. Overview of the properties of the ozonesonde measurements at Uccle and De Bilt. This table is adapted from Van Malderen et al. (2014).

\begin{tabular}{|c|c|c|}
\hline & Uccle & De Bilt \\
\hline Coordinates & $50^{\circ} 48^{\prime} \mathrm{N}, 4^{\circ} 21^{\prime} \mathrm{E} ; 100 \mathrm{~m}$ a.s.l. & $52^{\circ} 10^{\prime} \mathrm{N}, 5^{\circ} 18^{\prime} \mathrm{E} ; 4 \mathrm{~m}$ a.s.l. \\
\hline First launch & Jan 1969 & Nov 1992 \\
\hline Average frequency & 3 week $^{-1}$ & 1 week $^{-1}$ \\
\hline $\begin{array}{l}\text { Sonde type } \\
\text { Switch date }\end{array}$ & $\begin{array}{l}\text { Brewer-Mast } \\
\text { ENSCI ECC Z } \\
1 \text { Apr } 1997\end{array}$ & $\begin{array}{l}\text { SPC ECC 5A } \\
\text { SPC ECC 6A } \\
\text { 24 Jul 1997/1 Mar 2001* }\end{array}$ \\
\hline $\begin{array}{l}\text { RS type } \\
\text { Switch dates }\end{array}$ & $\begin{array}{l}\text { VIZ/RS80/RS92 } \\
\text { Jan 1990/Sept } 2007\end{array}$ & $\begin{array}{l}\text { RS80/RS92 } \\
\text { Nov } 2005\end{array}$ \\
\hline ECC SST & 0.5 & 1.0 \\
\hline Solution amount & $3.0 \mathrm{cc}$ & $\begin{array}{l}2.5 \mathrm{cc} \\
3.0 \mathrm{cc} \text { (from } 23 \mathrm{Nov} 1994)\end{array}$ \\
\hline Location $T_{\mathrm{p}}$ sensor & $\begin{array}{l}\text { in the box (from } 1 \text { Jan 1990) } \\
\text { in the pump (since Dec 1998) }\end{array}$ & $\begin{array}{l}\text { in the box } \\
\text { in the pump (from } 19 \text { Nov 1998) }\end{array}$ \\
\hline$I_{\mathrm{B}}$ measurement & $\begin{array}{l}\text { in laboratory } \\
\text { before exposure to } \mathrm{O}_{3}\end{array}$ & $\begin{array}{l}\text { in laboratory/at launch field } \\
\text { after exposure to } \mathrm{O}_{3}\end{array}$ \\
\hline
\end{tabular}

* The SPC ECC 6A is in use in De Bilt since 24 July 1997 but with an interception of more than 1 year (30 September 1999-1 March 2001) when the SPC ECC 5A was launched again.

lution at De Bilt changed from 2.5 to $3.0 \mathrm{cc}$ on 23 November, 1994.

The largest difference in the operating procedures between the Uccle and De Bilt stations (see also Table 1) is the measurement of the BGC. At Uccle, this value is measured in the laboratory before exposure to ozone. In De Bilt, $I_{\mathrm{B}}$ is measured after exposure to ozone and the value is kept small by changing (refreshing) the chemical solutions in the cell several times. The measurement, through the radiosonde system, takes places in the laboratory and/or at the launch field during the inflation of the balloon, typically a couple of hours after the ozonesonde preparation.

\subsection{Data correction methods}

The sonde data are processed according to Eq. (2), but design changes (e.g. the presence and location of the pump temperature sensor), differences in pre-flight operating procedures, and evolving guidelines following intercomparison campaigns led to wide variety of post-processing algorithms applied in the ozonesonde network. For instance, the background current is measured at different times during preflight preparation, e.g. before or after the sonde is exposed to a sampling flow with about $100 \mathrm{ppbv}$. This BGC can be assumed constant during the flight, equal to 0 for BM sondes, or, alternatively, a pressure-dependent BGC correction can be used ${ }^{2}$, assuming a small oxygen dependence with a gradual decline that is proportional to decreasing pressure and is negligible in the upper troposphere and stratosphere (Komhyr, 1986). In this latter case, the BGC is assumed to be caused by a small interference of oxygen reacting with $\mathrm{KI}$ in the cathode and therefore generating a small additional current (Smit et al., 2007).

Furthermore, it has been observed that at reduced air pressure, the pump flow rate $\Phi_{\mathrm{p}}$ in Eq. (2) declines due to pump leakage, dead volume in the piston of the pump, and the back pressure exerted on the pump by the cathode cell solution (Komhyr, 1967; Steinbrecht et al., 1998). This decrease in pump efficiency is corrected by multiplying the pump flow rate in Eq. (2) with a pump correction factor $C_{\mathrm{PF}}$ as function of air pressure, based on laboratory measurements of the pump efficiency at reduced pressures (Smit et al., 2007). The different pump efficiency correction profiles $C_{\mathrm{PF}}$ used worldwide for the BM and ECC sondes are, for example, shown in Fig. 2 of Stübi et al. (2008). They all smoothly increase with

\footnotetext{
${ }^{2} \mathrm{~A}$ pressure-dependent background current typically has the form $I_{\mathrm{B}}=I_{\mathrm{B}_{0}} \times \frac{P}{P_{0}}$, where $I_{\mathrm{B}_{0}}$ is the background current measured during pre-flight preparations at surface pressure $P_{0}$ (Smit and the Panel for ASOPOS, 2011). The Vaisala manual however proposes a second order correction for the SPC ECC sensor: $I_{\mathrm{B}}=I_{\mathrm{B}_{0}} \times$ $\frac{A_{0}+A_{1} \times P+A_{2} \times P^{2}}{A_{0}+A_{1} \times P_{0}+A_{2} \times P_{0}^{2}}$, with $A_{0}=0.00122504, A_{1}=0.0001241115$, and $A_{2}=-2.687066 \times 10^{-8}$
} 
Table 2. Overview of the most important properties of the different correction strategies applied at Uccle and De Bilt. More details can be found in the text and in Smit et al. (2012) for the O3S-DQA corrections.

\begin{tabular}{|c|c|c|c|c|}
\hline & \multicolumn{2}{|l|}{ Uccle } & \multicolumn{2}{|c|}{ De Bilt } \\
\hline & Operational (PRESTO) & $\begin{array}{l}\text { O3S-DQA } \\
\text { (only ECC) }\end{array}$ & Operational & O3S-DQA \\
\hline$\eta_{\mathrm{C}}$ correction & no $(=1)$ & no $(=1)$ & no $(=1)$ & $\begin{array}{l}\text { yes, for } 2.5 \mathrm{cc} \\
\text { solution }\end{array}$ \\
\hline$\Phi_{\mathrm{p}}$ efficiency correction & $\begin{array}{l}T, p \text { dependent } \\
\text { see Eqs. (4) and (6) }\end{array}$ & $p$ dependent & $p$ dependent & $\begin{array}{l}p \text {-dependent } \\
\text { humidification } \\
\text { effect corr. }\end{array}$ \\
\hline Correction profiles $C_{\mathrm{PF}}$ & $\begin{array}{l}\text { measured in-house } \\
\text { De Backer et al. (1998b) }\end{array}$ & Komhyr et al. (1995) & $\begin{array}{l}\text { Komhyr (1986) } \\
\text { Komhyr et al. (1995) } \\
\text { (from Nov 1998) }\end{array}$ & Komhyr (1986) \\
\hline$T_{\mathrm{p}}$ value used & $\begin{array}{l}\text { (estimated/measured) } T_{\mathrm{Box}}(\mathrm{BM}) \\
\text { measured } T_{\mathrm{Box}} / T_{\mathrm{p}}(\mathrm{ECC})\end{array}$ & measured $T_{\mathrm{Box}} / T_{\mathrm{p}}$ & measured $T_{\mathrm{Box}} / T_{\mathrm{p}}$ & measured $T_{\mathrm{Box}} / T_{\mathrm{p}}$ \\
\hline Corrections & & $\begin{array}{l}T_{\mathrm{Box}} \longrightarrow T_{\mathrm{p}} \\
T_{\mathrm{p}} \longrightarrow \text { "truest" } T_{\mathrm{p}}\end{array}$ & & $\begin{array}{l}T_{\mathrm{Box}} \longrightarrow T_{\mathrm{p}} \\
T_{\mathrm{p}} \longrightarrow \text { "truest" } T_{\mathrm{p}}\end{array}$ \\
\hline$I_{\mathrm{B}}$ used & $\begin{array}{l}I_{\mathrm{B}}=0 \text { or negative }(\mathrm{BM}) \\
\text { before } \mathrm{O}_{3} \text { exposure }(\mathrm{ECC})\end{array}$ & before $\mathrm{O}_{3}$ exposure & $\begin{array}{l}\text { after } \mathrm{O}_{3} \text { exposure } \\
\text { see Fig. } 4\end{array}$ & $\begin{array}{l}\text { after } \mathrm{O}_{3} \text { exposure } \\
\text { see Fig. } 4\end{array}$ \\
\hline$I_{\mathrm{B}}$ subtraction & constant & constant & $\begin{array}{l}\text { pressure-dependent } \\
\text { constant } \\
\text { (from } 5 \text { Nov 1998) }\end{array}$ & constant \\
\hline Total $\mathrm{O}_{3}$ normalisation & yes, pressure dependent & no & no & no \\
\hline $\mathrm{SO}_{2}$ correction & yes $(\mathrm{BM}) /$ no $(\mathrm{ECC})$ & no & no & no \\
\hline Altitude correction & yes (BM:VIZ RS)/no (ECC) & no & no & no \\
\hline
\end{tabular}

decreasing pressure and predominantly affect the upper part of the ozone profile.

Another common practise is the normalisation (linear scaling) of the ozonesonde profiles to an independently determined total ozone amount (measured by e.g. a Brewer or Dobson spectrophotometer). This is in particular important for BM sondes, because they have a typical response equivalent to about $80-90 \%$ of the actual ozone amount (SPARC-IOC-GAW, 1998). Therefore, the partial ozone column above the balloon burst altitude has to be estimated, either by the assumption of a constant mixing ratio or by applying satellite climatologies (e.g. McPeters and Labow, 2012).

\subsubsection{O3S-DQA corrections}

From the discussion in the previous paragraphs, it is obvious that there is a need for a standardisation of the operating procedures and a homogenisation of the ozonesonde time series (not only between different stations but also for a given station), which is the aim of the already mentioned O3S-DQA activity. This activity is, however, restricted to ECC sondes only, not for BM sondes. Consequently, for Uccle, the time series of ozonesonde measurements homogenised according to the O3S-DQA principles, starts with the introduction of ECC sondes in 1997.

The rationale, recommendations, and guidelines of the O3S-DQA activity are described in Smit et al. (2012). We here shortly give an overview of the proposed corrections for Uccle and De Bilt, also summarised in Table 2. The main focus of O3S-DQA is on the development and application of transfer functions to convert either $1.0 \% \mathrm{KI}$ concentration measurements to $0.5 \% \mathrm{KI} \mathrm{SST}$, or ENSCI measurements to SPC measurements, or vice versa, so that all ozonesonde data can be traced back to one of the two standards, SPC $1.0 \%$ or ENSCI $0.5 \%$. As the ECC data of De Bilt and Uccle, respectively, are measured with those standards, there is no need of applying a transfer function because the ratio is 1.0 to within $1.0 \%$. However, during the first 2 years of operation, the ozone sensors at De Bilt have been charged with only $2.5 \mathrm{~cm}^{3}$ of cathode sensing solution. In this case, only $\sim 96 \%$ of the ozone is captured by the sensing solution at $1000 \mathrm{hPa}$ ground pressure, but this deficit vanishes rapidly with decreasing pressures (Davies et al., 2003). Therefore, for these data, the absorption efficiency $\alpha_{\mathrm{O}_{3}}$ (a component of the conversion efficiency $\eta_{\mathrm{c}}$ ) is not longer equal to 1 and is processed by a pressure-dependent expression for pressures 


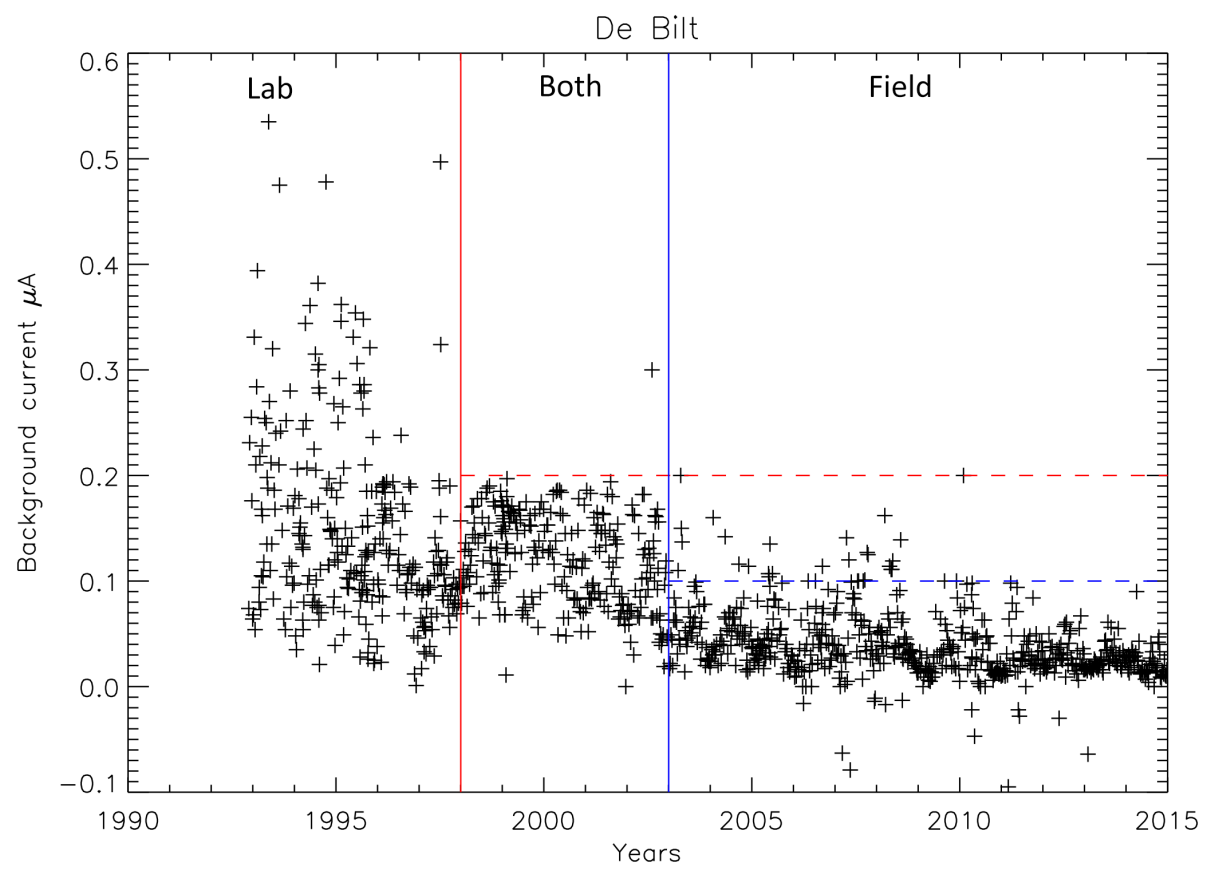

Figure 4. Time series of background current values measured after exposure to ozone at De Bilt. The vertical lines denote the periods from which the upper limits for the BGC (horizontal lines, same colour coding) were imposed. For more details, see the text.

above $100 \mathrm{hPa}$, so that it equals 0.96 for $1000 \mathrm{hPa}$ and 1.00 for $100 \mathrm{hPa}$.

For the O3S-DQA correction, both Uccle and De Bilt stations subtracted the BGC measured prior to launch from the measured electrical currents, i.e. the BGC is kept constant. Since at Uccle the recommended BGC measurement after ozone exposure is only recently available, the value recorded before ozone exposure is used. The average measured background current value is $0.018 \mu \mathrm{A}$ (around $0.075 \mathrm{mPa}$ or $1.5 \mathrm{ppbv}$ or $2.5 \%$ of tropospheric ozone). The BGC after ozone exposure is higher than the one measured before ozone exposure, but it never exceeds $0.1 \mu \mathrm{A}$ (around $0.37 \mathrm{mPa}$ or 3.75 to 18.5 ppbv or $7-17 \%$ of tropospheric ozone) at Uccle because this is the established upper limit for accepting the ozonesonde for launch. In De Bilt, to reduce the $I_{\mathrm{B}}$, the following strategy has been adopted: after exposure to ozone, the chemicals in the cell were changed (refreshed) as many times as necessary to get the $I_{\mathrm{B}}$ to a small value $(<0.2 \mu \mathrm{A}$ from 1998 onwards, $<0.1 \mu \mathrm{A}$ from 2003; see Fig. 4). The value for the BGC that is actually used for the correction is measured through the radiosonde system, at the end of the calibration procedure. This is typically 1 or $2 \mathrm{~h}$ after the rest of the procedure to condition and calibrate the ozone sensor. Normally the $I_{\mathrm{B}}$ has gone down significantly in this period. Before 1998, this value was measured in the laboratory, immediately after the calibration of the radiosonde. From November 2005 onwards the $I_{\mathrm{B}}$ was measured at the launch field during the inflation of the balloon. Between 1998 and 2005 the $I_{\mathrm{B}}$ was measured both in the lab and on the field; see Fig. 4. The value that is used for correcting the ozone profile changed in 2003 from "lab" to "field". The "field" values are typically lower than the "lab" values. Although the constant BGC subtraction with the measured values shown in Fig. 4 has been applied for the O3S-DQA correction in this paper, this remains questionable for the De Bilt record, as the measured BGCs are too high in the early years. As a matter of fact, the O3S-DQA guidelines would recommend to use a climatological value of $0.045 \pm 0.03 \mu \mathrm{A}$ for the BGC after exposure of ozone instead. So, on this point, these O3S-DQA guidelines were not followed for the De Bilt O3S-DQA correction applied here.

The ECC sondes now used in Uccle and De Bilt are equipped with a thermistor, mounted in a hole drilled in the pump body, to measure the pump temperature $T_{\mathrm{p}}$. However, the pump temperature needed in Eq. (2) is the actual temperature inside the cylindrical housing of the moving piston of the pump, which is about $1-3 \mathrm{~K}$ smaller than the measured $T_{\mathrm{p}}$, depending on the pressure (Smit et al., 2012). Within O3SDQA, a correction (with an uncertainty of about $\pm 0.5 \mathrm{~K}$ ) is proposed, based on simulation chamber measurements. For the periods during which the thermistor was located only in the box (and not in the pump) at Uccle and De Bilt (see Table 1), an additional pressure-dependent correction is applied (Eq. 9 in Smit and the Panel for ASOPOS, 2011), because the frictional heating of the moving piston of the pump gives an internal temperature within the pump base that is higher than the external pump temperature. Measurements in the simulation chamber pointed out that the differences between both 
temperatures were between 0.5 and $2 \mathrm{~K}$ at ground pressure but increased to a maximum in the range $7-10 \mathrm{~K}$ at $50 \mathrm{hPa}$ and then slightly decreasing towards lower pressures (Smit et al., 2007).

In Uccle, the pump flow rate is measured in the laboratory with a Brooks volume calibrator with a mercury ring. In De Bilt, a bubble flow metre is used for this measurement. However, this latter technique is susceptible to an offset due to the evaporation of water from the detector cell, which is positioned between the pump and the bubble flow metre: this is called the "humidification effect". The proposed correction method for this effect (Smit and the Panel for ASOPOS, 2011) is based on the temperature and relative humidity at laboratory conditions. These have been recorded in De Bilt for the majority of the flights. In the few cases when these conditions have not been recorded, they have been estimated from the meteorological conditions during the preparations of the sensor. More in general, the equilibrium pump temperature turns out to be about $2 \mathrm{~K}$ higher than the room temperature in which the volume calibrator is located (Komhyr et al., 1995; Smit et al., 2012). As a consequence, the actual pump flow rate at ground will be larger than the measured one by a factor of 1.007 and is corrected for accordingly for both stations. This value is then multiplied in Eq. (2) by the already mentioned pressure-dependent pump correction factor $C_{\mathrm{PF}}$, obtained from the laboratory measurements described in Komhyr (1986) for SPC (De Bilt), and described in Komhyr et al. (1995) for ENSCI (Uccle). These two curves differ by about $1 \%$ at $10 \mathrm{hPa}$ and $3 \%$ at $5 \mathrm{hPa}$.

Finally, the O3S-DQA initiative recommends not to use the total ozone normalisation for ECC ozonesondes, but still to calculate and report the scaling factor when distributing the data through international databases. It can be used as an additional quality indicator of the ozone sounding data. Furthermore, although both Uccle and De Bilt switched from RS80 to RS92 radiosondes and the corresponding change in the pressure sensor affects the vertical ozone profile (Steinbrecht et al., 2008; Stauffer et al., 2014; Inai et al., 2015), we follow the O3S-DQA recommendation to not apply any altitude correction to the profile. Additionally, this radiosonde change also caused a change in the Vaisala interface card and hence the pump temperature sensor, so that an effect on the recorded pump temperatures cannot be excluded (see Fig. 2 in Van Malderen et al., 2014, which shows a $2{ }^{\circ} \mathrm{C}$ decrease at $700 \mathrm{hPa}$ ). Since this effect is not quantified, no correction can be applied.

\subsubsection{The Uccle corrections}

In Uccle, after using BM sondes for about 25 years, the transition was made to ENSCI ECC sondes in 1997. Therefore, the operational post-flight algorithms at Uccle are developed primarily to construct a homogeneous time series, without any break caused by this transition. The details of these corrections can be found in De Backer (1999) and are presented in Table 2. The main aim of the correction strategy is to combine the pump efficiency correction with the total ozone normalisation, as the latter is required for BM sondes. Therefore, we will use the acronym PRESTO (pressure- and temperature-dependent total ozone normalisation) for this correction method in the remainder of the paper. This method is operationally applied only at Uccle but could also be adapted to other ozonesonde site datasets. In practise, the following steps are taken (see also Table 2). Performing steady-state measurements with BM and ECC sondes in a vacuum chamber at different pressures and temperatures, De Backer et al. (1998a) found that the efficiency of the miniature pumps is not only a function of pressure but also dependent on the temperature of the pump, especially for BM sondes, and the following temperature correction was derived:

$k(T)=a_{0,0}+a_{0,1} \cdot T+a_{1,0} \cdot \log _{10}(p)+a_{1,1} \cdot T \cdot \log _{10}(p)$,

where $k(T)$ represents the factor by which the time to pump $100 \mathrm{~mL}\left(\propto 1 / \Phi_{P}\right.$ in Eq. 2$)$ of air at $20^{\circ} \mathrm{C}$ must be multiplied to obtain the time at temperature $T$ (in ${ }^{\circ} \mathrm{C}$ ), and $a_{i, j}$ regression coefficients. These factors are visualised for different pressures and temperatures in Figs. 2 and 3 in De Backer et al. (1998a) for BM and ENSCI ECC sondes, respectively. Then, based on vacuum chamber steady-state measurements with varying pressure (but now with fixed temperature) of $200 \mathrm{BM}$ sondes and 150 ENSCI sondes, De Backer et al. (1998b) obtained pump correction factors, $C_{\mathrm{PF}}$, that are higher than the corresponding standard correction factors (Komhyr and Harris, 1965; Komhyr et al., 1995, for BM and ENSCI ECC sondes, respectively). Both sets of the obtained measurements could be fitted by a similar equation for the time needed to pump $100 \mathrm{~mL}$ of air at pressure $p$ :

$t(p)=t\left(p_{0}\right) \frac{1+\sqrt{\frac{b}{p}}}{1+\sqrt{\frac{b}{p_{0}}}}$,

where $p_{0}$ the ground pressure and $b$ is a parameter depending on the sonde type. Inspired by this equation, De Backer et al. (1998b) proposed the following empirical shape for the pressure dependency of the pump flow rate (equal to the pump flow correction factor $C_{\mathrm{PF}}$ ):

$C_{\mathrm{PF}}(p)=c_{0} \frac{1+\sqrt{\frac{b}{p}}}{1+\sqrt{\frac{b}{p_{0}}}}$,

where $c_{0}$ is the ground calibration factor determined with a calibrated ozone source $\left(320 \mu \mathrm{g} \mathrm{m}^{-3}\right.$ running through the ozone sensor during $10 \mathrm{~min}$ ) before launch and $b$ is a parameter dependent on the performance of the sensor, determined in such a way that the integrated amount of ozone in the profile (increased with the residual amount of ozone) is equal to the total ozone measured with a spectrophotometer at the 
same site. In other words, the pump flow correction factor $C_{\mathrm{PF}}$, determined after the temperature dependency correction of the pump flow rate in Eq. (4), is adjusted for each pump individually as to match both the single point calibration of the ozone sensor at the laboratory and the total ozone column value measured on site. For completeness, we add that the residual amount of ozone is calculated with either the constant mixing ratio assumption or the McPeters and Labow (2012) satellite climatology, depending on the balloon burst altitude, as prescribed by WMO (1987). When the ground calibration factor $c_{0}$ is not available (i.e. before May 1992), the value $c_{0}$ in Eq. (6) is estimated from a relation between $c_{0}$ and the total ozone scaling factor, depending on the quality of the pumps. Since the movement of the manufacturing company seemed to have resulted in an inferior quality of the pumps used after April 1989, two different relationships have been determined. Applying this correction method to both BM and ECC ozonesondes, De Backer et al. (1998a) could lower the ozone differences of 26 dual soundings at Uccle to within $3 \%$ over almost the entire altitude range, while Lemoine and De Backer (2001) could reduce the drift between SAGE II and ozonesondes from -0.51 to $-0.07 \% \mathrm{yr}^{-1}$ between 17 and $22 \mathrm{~km}$ with non-significant values at the $2 \sigma$ level at all altitudes.

The above described procedure for the pump efficiency correction and total ozone normalisation makes up the largest difference with the so-called standard corrections or the O3SDQA corrections (for ECC sondes). However, other smaller differences exist and some additional corrections, especially for BM sondes, have been developed at Uccle and are applied operationally there. These are discussed in Appendix A.

\subsubsection{The De Bilt corrections}

The focus of the 23-year-old ozonesonde programme of the De Bilt station lies more on the satellite validation and the Match campaign for the determination of stratospheric polar ozone losses ${ }^{3}$, rather than the creation of a homogeneous long-term data record. As a consequence, small changes in their procedures and data processing have occurred several times. However, the data from the ozone sensor has been digitised on board the sonde, and all original raw data are still available. It is not our purpose to discuss here all changes that have been made over time but rather to concentrate on the ones that affect the homogeneity of the data series, also presented in Table 2 .

The most significant changes took place in late 1998, when the participation of De Bilt in the Match campaign started and an agreement on standardisation of operating procedures and data processing was reached among the participating ozonesonde stations. Therefore, from November 1998 onwards, the environmental conditions in the laboratory were

\footnotetext{
${ }^{3}$ http://www.awi.de/en/research/research_divisions/climate_ science/atmospheric_circulations/expeditions_campaigns/ozone_ loss_campaigns_match/
}

recorded, the pump temperature instead of the box (or sensor) temperature was measured, another pump efficiency correction table was used (Komhyr et al., 1995 instead of Komhyr, 1986), the background current value was reduced by adopting a new measurement strategy (see above), and the constant BGC subtraction was applied.

Most critical for the homogeneity in the De Bilt dataset is the BGC. Before late 1998, the measured BGC values were too high (see Fig. 4), so that the BGC subtraction led to an underestimation of the total ozone column from the integrated profile with respect to the co-located Brewer instrument's value. Because a pressure-dependent correction subtracts a smaller BGC through the profile than the subtraction with a constant value - the subtracted BGC equals the measured one at ground pressure and then decreases with increasing pressure (see Sect. 2.2) - the pressure-dependent correction with the measured $\mathrm{BGC}$ for the period before the end of 1998 is still preferred. As the BGC values in De Bilt decreased over time (see Fig. 4), this trend will have an impact on the calculated trends of (in particular tropospheric) ozone; see Sect. 4. However, the change of the BGC subtraction method might also generate an artificial trend in the ozone profile data series. Furthermore, as an ozone destruction filter is used for the BGC measurement, a seasonally dependent offset in the ozone profile is a distinct possibility if the efficiency of this filter is not equal to $100 \%$. This remark also applies to the Uccle dataset, where an ozone destruction filter is used too for measuring $I_{\mathrm{B}}$.

\section{Impact on the average ozone profiles}

The different possible post-processing steps described in the previous section all have an impact on the final ozone profile. In this section, we will quantify these impacts on the average ozone profiles, first for Uccle and De Bilt separately. Thereafter, we will compare the resulting average ozone profiles of both stations.

\subsection{Uccle}

As two types of ozonesondes have been used at Uccle, we will treat them separately in this section.

\subsubsection{The BM 1969-1996 time series}

To visualise the influence of the different steps in the Uccle PRESTO corrections on the average ozone profile obtained by BM sondes, we show in Fig. 5 the relative differences to the profile obtained by applying only the correction of the pump efficiency decrease with the standard correction factors (Komhyr and Harris, 1965). A first thing to note is that applying the total ozone normalisation by multiplying the profile with a scaling factor (green curve in Fig. 5) causes a relative ozone increase of 20-25\% throughout the profile compared with the reference average ozone profile. This number is in 


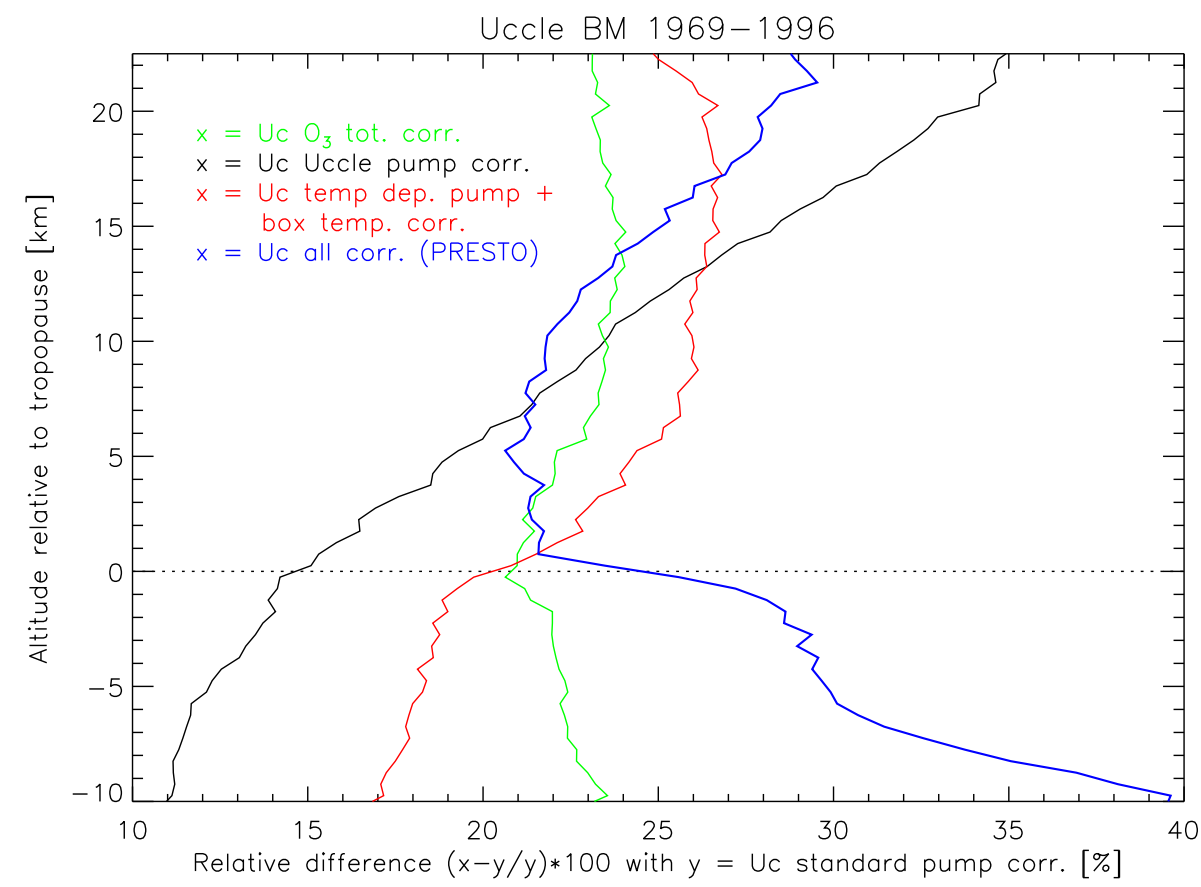

Figure 5. Relative differences of the average Uccle ozone profile calculated for different correction strategies with respect to the average ozone profile obtained by applying the standard pump efficiency correction factors. The average ozone profiles are calculated for the entire BM 1969-1996 observation period and in layers of $0.5 \mathrm{~km}$ height, relative to the tropopause height. For more details, see the text.

agreement with the fact that BM sondes of Uccle are known to have a typical response equivalent to about $80 \%$ of the actual ozone amount with total ozone scaling factors in the range 1.1-1.3 (De Backer, 1999).

The combination of the correction for the pump efficiency decrease with decreasing pressure and the total ozone normalisation leads to a smaller relative difference in the troposphere (around 10-15\%) and higher relative differences above the ozone maximum (see black curve in Fig. 5). This can be explained by the fact that the used pump correction factors, determined in the vacuum chamber at Uccle, are higher than the standard correction factors (see e.g. Fig. 2 in Stübi et al., 2008) and by the redistribution of the total ozone amount over the entire profile. With our combined method, layers hardly contributing to the total ozone amount, like the troposphere, will be exposed to smaller ozone normalisation scaling factors, as should be obvious from the figure. Additionally, the poorer performance of the pump for decreasing temperatures is also corrected for at Uccle. However, as without any box temperature correction a constant value of $300 \mathrm{~K}$ is assumed for BM soundings before 1990, we show in Fig. 5 (red curve) the combined effect of the contributions of the temperature dependency of the pump efficiency and the pump temperature corrections (also the extrapolations for the period before April 1989; see Appendix A). These pump temperature effect corrections have a large impact on the average ozone profile, when we compare with the previously described correction (black curve), especially in the upper parts of the atmosphere, where the pump efficiency is most affected by the lower temperatures and the box temperature deviates most from the $300 \mathrm{~K}$ standard value. Of course, these effects have been shifted over the entire profile by the redistribution of the total amount of ozone.

The additional corrections included in the operational PRESTO correction for the 2 first decades of the time series (see Appendix A) especially affect either the upper part of the profile (the altitude correction) or the tropospheric ozone (the $\mathrm{SO}_{2}$ interference and the correction for a negative background current), resulting in the blue curve in Fig. 5. With respect to the standard pump correction, the entire set of operational corrections gives a roughly $30 \%$ ozone increase in the free troposphere and even between 30 and $40 \%$ in the lower troposphere/boundary layer. The impact of the PRESTO correction is lowest in the lower stratosphere (around 20\% ozone increase) and increases again from the ozone maximum to reach again $30 \%$ in the upper parts of the sounding. The PRESTO post-processing steps have been developed based on simulation chamber tests, double soundings, and the comparison of ascent and descent profiles and have been validated against reference satellite data (SAGE II; Lemoine and De Backer, 2001).

\subsubsection{The ECC 1997-2014 time series}

For the ECC time series, we again chose to confront the corrected profiles with the standard pump corrected (average) 


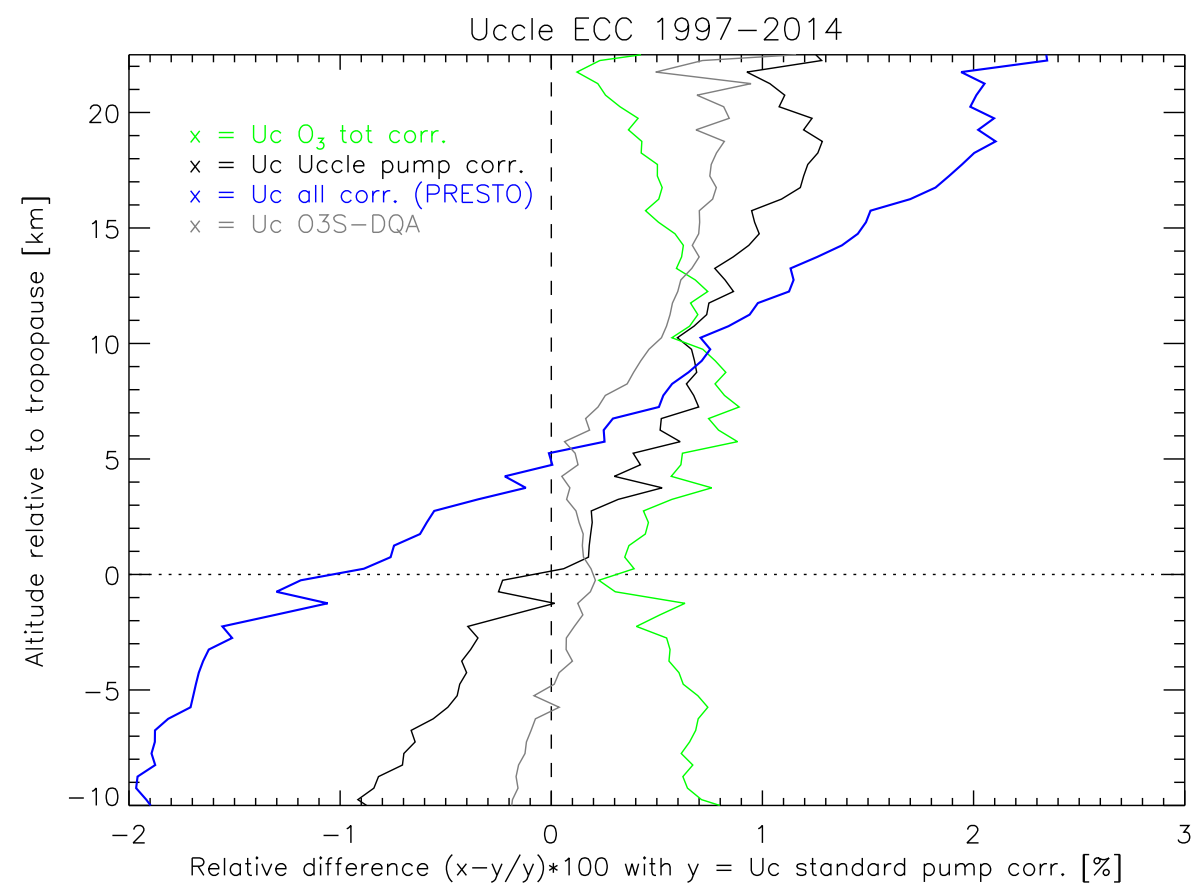

Figure 6. Relative differences of the average Uccle ozone profiles calculated for different correction strategies with respect to the average Uccle ozone profile obtained by applying the standard pump efficiency correction factors. The average ozone profiles are calculated for the ECC 1997-2014 observation period and in layers of $0.5 \mathrm{~km}$ height, relative to the tropopause height.

Uccle ECC profile in Fig. 6. The alternative correction methods at Uccle produce average profiles within $\pm 2 \%$ of this reference profile, a number even smaller than the estimated uncertainties for the Uccle ECC profiles (see Fig. 3). These smaller relative differences compared to the average BM profiles shown in Fig. 5 are due to the nearly $100 \%$ response equivalent of the actual ozone amount of ECC sondes. Indeed, the total ozone normalisation by simple linear scaling increases the ozone relatively by less than $1 \%$ throughout the profile (see green curve in Fig. 6). Consequently, the relative differences for the average profiles processed by the Uccle pump efficiency correction method, with a pressuredependent total ozone normalisation (in black in Fig. 6), are within the same range. They increase with decreasing pressure, because the measured pump efficiency correction factors in the vacuum chamber in Uccle are higher than the standard correction factors; see e.g. Fig. 2 in Stübi et al. (2008). Introducing the temperature dependence of the pump efficiency in the corrections (to complete the PRESTO correction; blue curve in Fig. 6) adds another 1\% relative difference in the troposphere and the upper stratosphere. For ECC sondes, the relative differences only due to this correction (hence applying only Eq. 4, not shown in Fig. 6) increase from around $0 \%$ in the troposphere to a maximum of $4 \%$ at balloon burst altitudes.

The Uccle O3S-DQA corrected profile is also included (grey curve in Fig. 6), and it resembles the chosen reference most (within $\pm 1 \%$ ), as could be expected from meth- ods using the same standard pump efficiency correction factors (and applying no total ozone normalisation). The difference is largest at high altitudes due to the pump temperature correction applied in the O3S-DQA corrections. The difference between the two correction methods at Uccle (PRESTO and O3S-DQA) is largest in the troposphere (about $2 \%$ ), which can be explained by the redistribution of the total ozone amount over the entire profile interacting with the pressure- and temperature-dependent pump efficiency correction. Especially the temperature dependency correction amplifies the differences with the O3S-DQA correction (compare the black, blue, and grey curves in Fig. 6), also at altitudes above the ozone maximum.

\subsection{De Bilt}

Now we compute for the entire observation period of De Bilt (1993-2014) the average profiles of the two different correction strategies: one generated according to the O3SDQA guidelines and another one corrected by the De Bilt operational algorithms (see Table 2). In Fig. 7 (green line), we compare the vertical profile of the relative differences between both those average profiles. A first important note is that the O3S-DQA average profile has smaller ozone amounts at all altitude levels. The relative differences between both corrections are smallest at the surface (around $2 \%$ ) and at the ozone maximum (around 2\% for around $10 \mathrm{~km}$ above the tropopause) and largest at the tropopause 


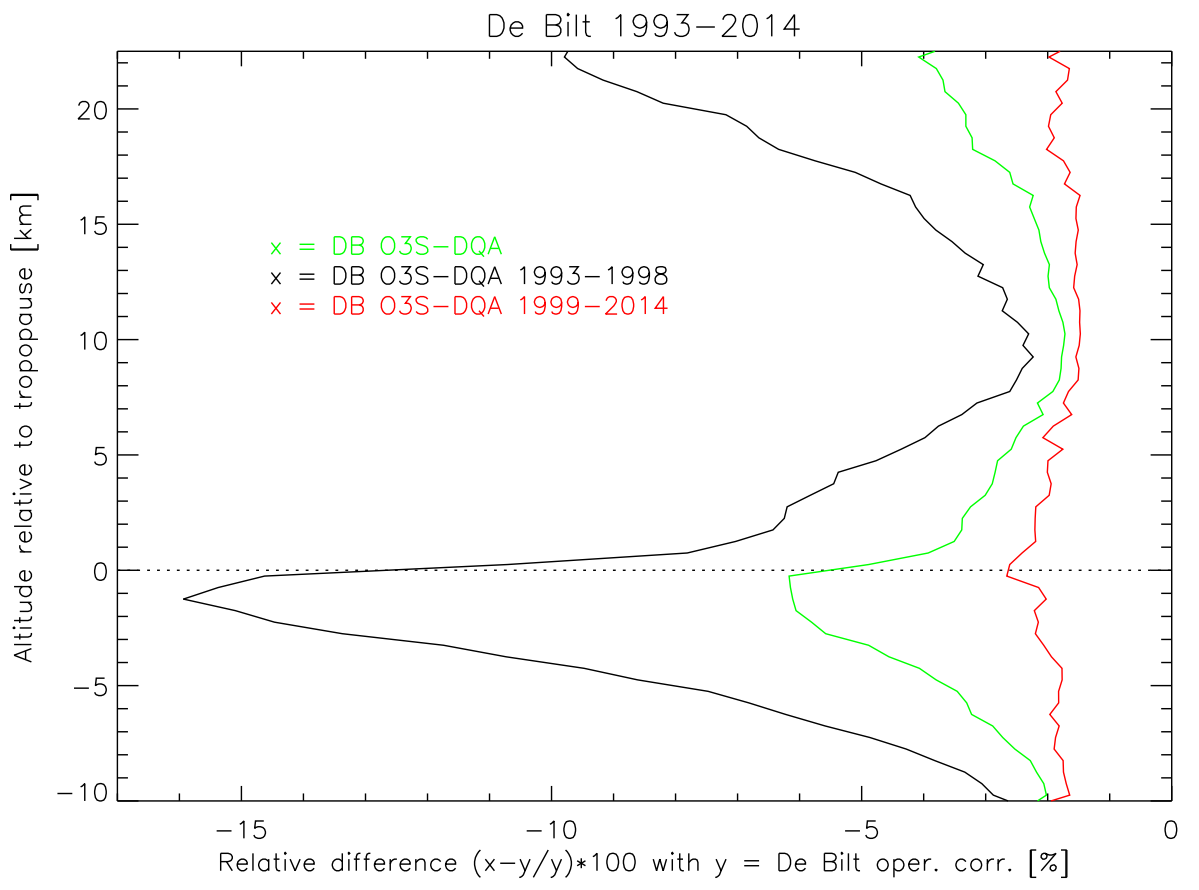

Figure 7. Relative differences of the average De Bilt O3S-DQA corrected ozone profiles calculated for different periods with respect to the average De Bilt ozone profile obtained by applying the operational corrections for the same periods. The average ozone profiles are calculated in layers of $0.5 \mathrm{~km}$ height, relative to the tropopause height.

(about $6 \%$ ). Above the ozone maximum, the relative differences increase to a $4 \%$ at burst altitude. The variation of these relative differences in altitude is entirely caused by the differences in the correction and operating procedures before the end of 1998 (black curve in Fig. 7). From November 1998 on, the MATCH standard operating procedures were applied in the operational chain at De Bilt, resulting in an average profile differing by only $2 \%$ at all altitudes with the O3S-DQA corrected profile for the same period (red curve in Fig. 7). Before 1998, the large relative differences in especially the free troposphere (even more than $15 \%$ ) can be ascribed to the different background current correction strategies applied in the O3S-DQA and operational datasets. In both cases, the same (relatively high) measured value for the BGC is used, but this (constant) value is subtracted at all pressure levels for the O3S-DQA correction and a pressuredependent $\mathrm{BGC}$ subtraction is applied for the operational correction. Because the subtracted BGC value decreases with increasing pressure in the latter case, the O3S-DQA correction results in lower ozone partial pressures at all pressure levels. The relative differences between the two average profiles are therefore largest in this period at those levels where the impact of the BGC on the measurements is highest (the free troposphere; see Fig. 3) and the difference between the subtracted BGC values is largest (at the lowest pressures; see Fig. 7). However, because the measured background current values are so high before 1998 (see Fig. 4), BGC values in the range $0.1-0.2 \mu \mathrm{A}$ correspond to about $3.5-7 \mathrm{ppbv}$ of ozone at surface and about $25-30 \mathrm{ppbv}$ in the upper troposphere at $200 \mathrm{hPa}$, which easily can introduce differences of $15 \%$ or larger when using either a constant (O3S-DQA) or a pressure-dependent (operational) BGC correction. Near the ground, both BGC correction methods subtract the same $\mathrm{BGC}$ value, and the differences shown here are due to the O3S-DQA corrections of the pump flow rate at the ground: the correction for the humidification effect and the piston temperature.

\subsection{Comparison of Uccle and De Bilt}

In this section, we focus on the Uccle-De Bilt average ozone profile differences. Because the Uccle data series has been built up with two different types of ozonesondes (BM and ECC) in 1993-2014 (the time interval of the De Bilt series), we make the comparison with De Bilt for each type separately.

\subsubsection{Uccle BM versus De Bilt ECC: 1993-1996}

For the comparison of the average profiles of Uccle, gathered by $\mathrm{BM}$ ozonesondes, and De Bilt, we now take the average profile of the Uccle PRESTO corrected data as the reference in Fig. 8 instead of the unrealistic non-total ozone corrected BM profiles used as reference in Fig. 5. The relative differences between the standard pump corrected average profile - but now in combination with a total ozone normalisation by simple linear scaling - with the Uccle PRESTO average 


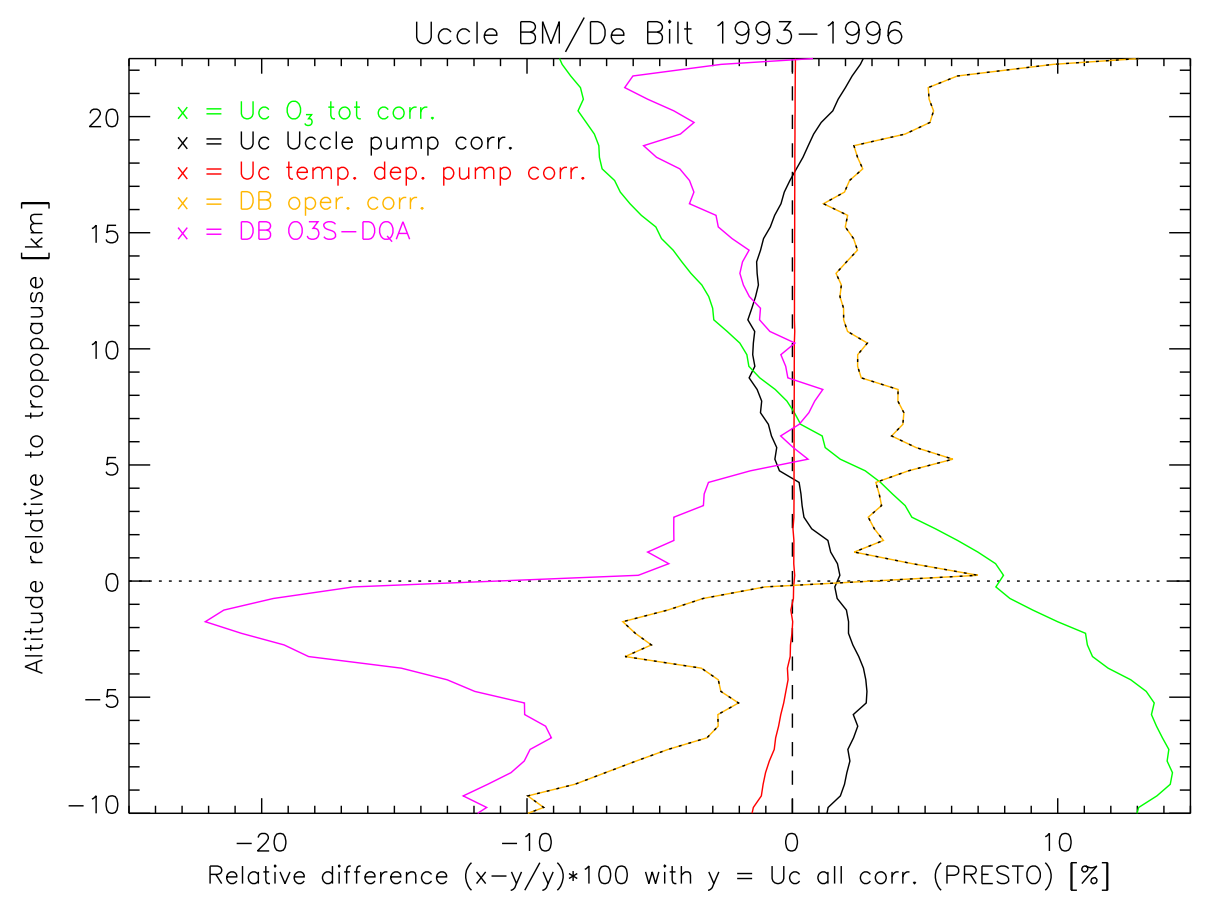

Figure 8. Relative differences of the average Uccle and De Bilt ozone profiles calculated for different correction strategies with respect to the average Uccle ozone profile obtained by applying the operational PRESTO correction. The average ozone profiles are calculated for the 1993-1996 observation period, when BM sondes were in use in Uccle, and in layers of $0.5 \mathrm{~km}$ height, relative to the tropopause height.

profile (see the green curve in Fig. 8) vary between $+15 \%$ in the lower troposphere and almost $-10 \%$ at burst altitudes.

We first concentrate on the Uccle-De Bilt comparison in the stratosphere. A first thing to note is that the developed correction algorithms PRESTO in Uccle are able to reduce the relative stratospheric ozone differences with both De Bilt corrections mostly to less than about $\pm 5 \%$ (see the gold dotted and magenta curves in Fig. 8). The Uccle and De Bilt average profiles show a very similar vertical ozone distribution in the stratosphere but with higher ozone partial pressures (by 2-6\%) for the De Bilt operational corrections (gold dotted curve) and lower (except at the ozone maximum) ozone partial pressures of at most $5 \%$ for the O3S-DQA corrections (magenta curve).

In the troposphere, both the De Bilt corrections result in lower ozone amounts compared to the Uccle PRESTO corrected ozone partial pressures, ranging from 10 to $22 \%$ for the O3S-DQA and from 2 to $10 \%$ for the operational corrections. With the high measured background currents at De Bilt, especially during this time period, these large differences can be expected with either BGC correction method. For the Uccle BM sondes, no BGC correction was applied. Another reason for the higher ozone amounts in the troposphere above Uccle could be the more urban area at Uccle (Brussels) and consequently higher emissions of ozone precursors like $\mathrm{NO}_{x}$, methane, $\mathrm{CO}$, volatile organic compounds (VOCs), etc. However, in this context, we refer again to the study of Staufer et al. (2014), who found upper-tropospheric ozone overestimations of up to $25 \%$ for the BM sondes flown at Hohenpeissenberg, Payerne, and Uccle from 1994 to 1997 compared to the MOZAIC aircraft measurements. In contrast, previous intercomparison studies at one site between $\mathrm{BM}$ and ECC ozonesondes reported on lower-tropospheric ozone measurements by the BM sondes with ranges between -10 to $-20 \%$ at Canadian stations (Tarasick et al., 2002), $-25 \%$ at Australian sites (Lehmann, 2005), $\pm 5 \%$ at Payerne (Stübi et al., 2008), and $-3 \%$ at Uccle (De Backer et al., 1998a). We therefore can conclude that the tropospheric ozone differences between the operational corrected profiles at Uccle and De Bilt are consistent with literature reports on BM-ECC comparisons at one site, but with the opposite sign. Based on 65 quasi simultaneous soundings at Uccle and De Bilt between December 1992 and August 1995, De Backer et al. (1998b) found significantly higher BM ozone readings at Uccle from the ground (by more than $20 \%$ ) up to $300 \mathrm{hPa}$. It should, however, be noted that the operational correction of BM sondes in use at that time was the standard pump correction with simple scaling for the total ozone normalisation (i.e. the green curve in Fig. 8). As a consequence, the differences obtained here for the entire samples at Uccle and De Bilt between 1993 and 1996 are very similar to the ones of this earlier study. 


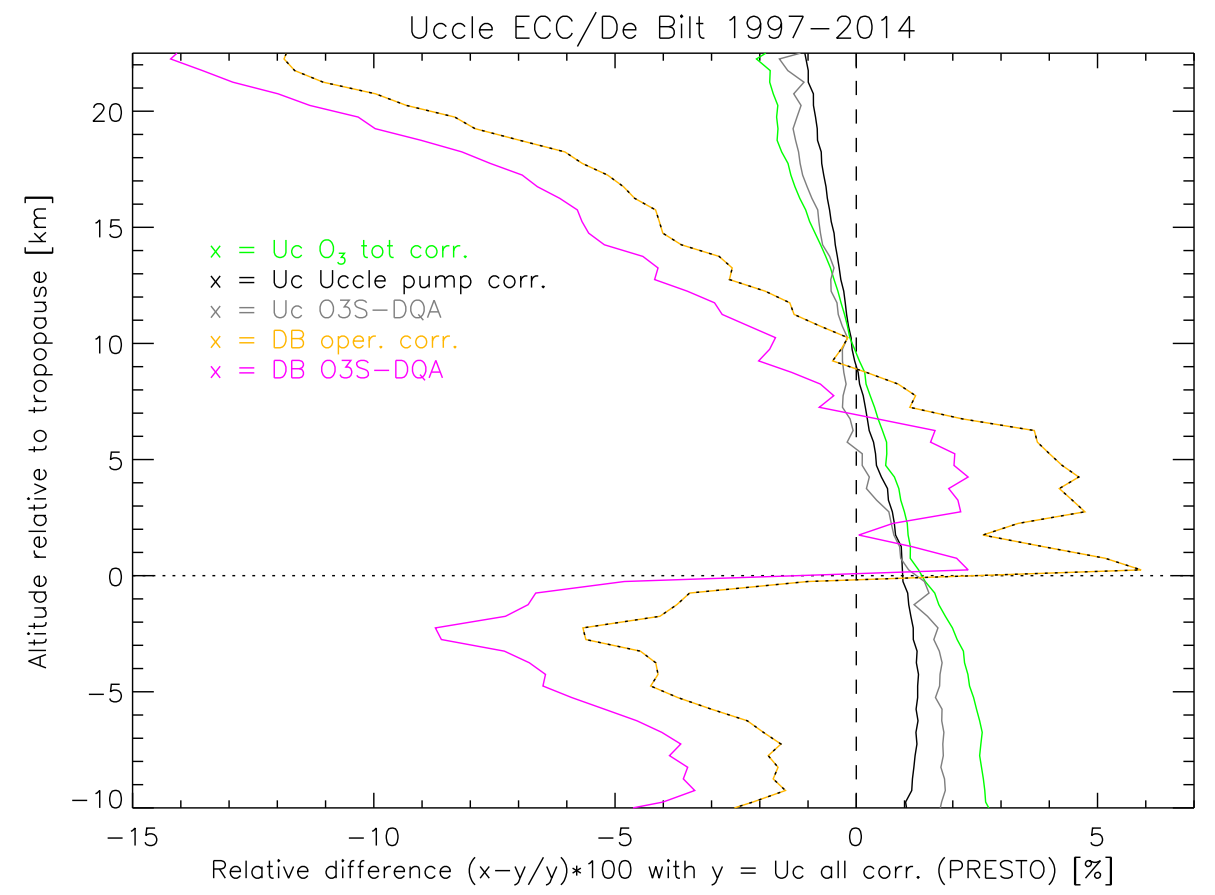

Figure 9. Relative differences of the average Uccle and De Bilt ozone profiles calculated for different correction strategies with respect to the average Uccle ozone profile obtained by applying the operational PRESTO correction. The average ozone profiles are calculated for the 1997-2014 observation period, when both stations were using ECC ozonesondes, and in layers of $0.5 \mathrm{~km}$ height, relative to the tropopause height.

\subsubsection{Uccle (Z-ECC, 0.5 \%) versus De Bilt (SPC ECC, $1 \%)$ : 1997-2014}

In this section, we compare the average profiles during the time period in which both stations launched ECC ozonesondes, although different types and with different SSTs. We therefore refer to Fig. 9. The most striking feature in this figure is the apparent dependency of the relative De Bilt differences with the Uccle PRESTO corrected average profile (magenta and gold dotted curves) on the measured ozone concentrations. Indeed, the relative differences are closest to 0 at the ozone maximum altitudes (see the Uccle average ozone profile in Fig. 3) and most distinct from 0 at the layers with the lowest ozone amounts (upper troposphere and upper range of the stratosphere). In particular, at burst altitudes, the relative differences between the Uccle and De Bilt ozone partial pressures can amount to up to $10 \%$, independently of the used correction method. Of course, measuring the ozone concentrations above $25 \mathrm{~km}$ is the most challenging for ozonesondes due to e.g. the pump efficiency decrease and the evaporation of the sensing solutions, but this number exceeds substantially the quoted $3 \%$ difference at $5 \mathrm{hPa}$ between the standard pump efficiency factor used at De Bilt and Uccle for the O3S-DQA corrections. The agreement between the Uccle and De Bilt average ozone profiles in the lower stratosphere is fairly good, around $5 \%$ at most. A relative difference around $5 \%$ is achieved for the troposphere, somewhat less for the boundary layer $(2-5 \%)$, and somewhat more for the upper troposphere (5-9\%), depending on the applied correction method. The agreement between the tropospheric ozone measurements at both sites is better compared to the Uccle BM period (compare Figs. 8 and 9) and similar (within $\pm 5 \%$ ) in the stratospheric layers below the ozone maximum, but it is worrying that the ECC measurements at both sites have, in the mean, higher ozone discrepancies in the upper altitude levels reached by the balloons with respect to the BM-ECC comparisons in 1993-1996.

To interpret those relative ECC ozone differences between Uccle and De Bilt, it might be easier to translate those in terms of the average ozone profile at both sites, and therefore, from Fig. 9, it can be inferred that higher tropospheric ozone amounts are measured at Uccle than at De Bilt, but lower ozone concentrations in the lower stratosphere. On average, the ozone maximum is located at lower altitudes at De Bilt than at Uccle, and above the ozone maximum the Uccle ozonesondes measure higher ozone amounts than the De Bilt ozonesondes. These differences in the average vertical ozone distribution between both stations apply only for the ECC period (compare Fig. 9 with Fig. 8), but in particular also for the periods in which both stations were using the same radiosonde type (RS80: 1997-November 2005; RS92: September 2007-2014). Therefore, those differences between Uccle and De Bilt do not seem related to an offset in the radiosonde pressure measurements between both 
sites, as was thoroughly checked. In contrast, differences in balloon ascent rates at both sites, on average $5.6 \mathrm{~m} \mathrm{~s}^{-1}$ for De Bilt and $7.5 \mathrm{~m} \mathrm{~s}^{-1}$ for Uccle for the 1997-2014 period, might affect the vertical ozone profile measurements, taking the ECC sensor response time of 20-30 s into account (Smit and Kley, 1998). Higher balloon ascent rates will therefore result in measuring the ozone maximum at higher altitudes (40-60 m with the average ascent rates quoted here) and in obtaining higher ozone concentrations at the upper stratosphere, where the ozone concentrations are decreasing with height above the ozone maximum. This is exactly what is observed when comparing the Uccle data with De Bilt. The higher tropospheric ozone amounts measured at Uccle than in De Bilt can be explained by the fact that the subtracted BGC values in Uccle (before exposure to ozone) are smaller than those measured (after exposure to ozone) and subtracted in De Bilt. However, different tropospheric ozone concentrations at Uccle and De Bilt might also be expected due to different environmental conditions, especially in the boundary layer (a hint is given in Fig. 2).

As the differences in the average vertical ozone distribution between both stations show some seasonal (as can be expected from Fig. 2) and interannual variability, geophysical differences between both sites cannot be completely ruled out as a possible cause. For example, we analysed the vertical temperature distribution obtained from the radiosonde measurements (also for the different types separately) at both sites. At all altitudes, we observed higher temperatures in Uccle than in De Bilt, with e.g. relative differences around $2 \%$ in the $25-30 \mathrm{~km}$ altitude range. These higher temperatures above Uccle in these layers might be linked to the higher ozone amounts measured there, compared to De Bilt. Moreover, from the ozone climatology obtained by merging ozone profile data of ozonesonde measurements with data from Aura MLS (McPeters and Labow, 2012), we calculated the monthly gradients (in kilometres per degree) of the ozone maximum altitude for the $40-60^{\circ}$ north latitude band. We found a clear seasonal cycle in the ozone maximum altitude gradients between Uccle and De Bilt and differences in the altitudes of the ozone maximum of the order of $0.7 \mathrm{~km}$ can be expected. This corresponds with the observations in our datasets as discussed above.

Finally, we focus on whether or not the uniform O3S-DQA corrections for the Uccle and the De Bilt stations result in a closer agreement of their average profiles. The relative differences between the two correction methods at De Bilt (in magenta and gold dotted in Fig. 9) vary between 2 and $4 \%$, with the larger value for the upper troposphere-lower stratosphere (UTLS) region. Based on Fig. 9, we can conclude that only for the lower stratosphere, the layers below the ozone maximum, the O3S-DQA corrections effectively reduce the relative differences between the Uccle and De Bilt ozone partial pressures. In the troposphere, the O3S-DQA corrections enhance the relative differences compared to the operational correction methods at Uccle and De Bilt. In the upper- stratospheric layers, the O3S-DQA correction at De Bilt increases the differences with Uccle, but the opposite is true for the O3S-DQA correction at Uccle. So, we must conclude that the homogenisation of the correction methods did not give an overall closer agreement between the ozone profile measurements at Uccle and De Bilt.

\section{Impact on the vertical ozone trends}

In this section, we will study the long-term time behaviour of the Uccle and De Bilt ozone series, which span different time periods. Therefore, we subtract the average annual cycle shown in Fig. 2 from the monthly mean time series in Fig. 1 to create the monthly anomaly time series of the different atmospheric layers (see Fig. 10). It is clear from this figure that the calculated ozone trends depend on the considered atmospheric layer, time period, and station. Moreover, here we will analyse the impact of the different correction strategies on the resulting vertical ozone trends, for different periods. To determine these trends, we first calculate the monthly anomalies of ozone partial pressures in layers of $1 \mathrm{~km}$ height, relative to the tropopause height. Then, for each of these layers, (robust) trends are estimated from the monthly anomaly time series by simple linear regression, as is also done in Fig. 10. We did not apply a multiple linear regression model (e.g. Harris et al., 2015) to calculate trends, because the focus is here on differences between trends rather than on the trend values themselves. Compared to the average ozone profile calculation, we chose a lower vertical resolution because the trend estimation is more sensitive to the number of available measurements per layer. Nevertheless, we stress that the results are comparable when using the identical vertical resolution as for the average profiles.

\subsection{The Uccle BM time series: 1969-1996}

We first concentrate on the Uccle BM dataset, extending from 1969 to 1996. For the different correction steps present in Fig. 5, the estimated relative trends are shown in the same colour coding in Fig. 11. A first thing to note is that, although the relative differences between the standard pump corrected and simple total ozone normalised average profiles were in the range of 20-25\% (see Fig. 5), the differences in the vertical trends calculated from both sets of corrected profiles are very small $\left(0-2 \%\right.$ decade $^{-1}$; see the green and cyan curves in Fig. 11). These trends are strongly positive in the troposphere (between +20 to more than $40 \%$ decade $^{-1}$ ) and negative in the stratosphere (except in the lowermost stratosphere), with the lowest values around $-10 \%$ decade $^{-1}$. Moreover, combining the correction for the pump efficiency decrease as a function of pressure with the total ozone normalisation (black curve in Fig. 11) also hardly affects the resulting vertical trend values compared to the previous two corrections. As a consequence, these different correction strategies do not in- 


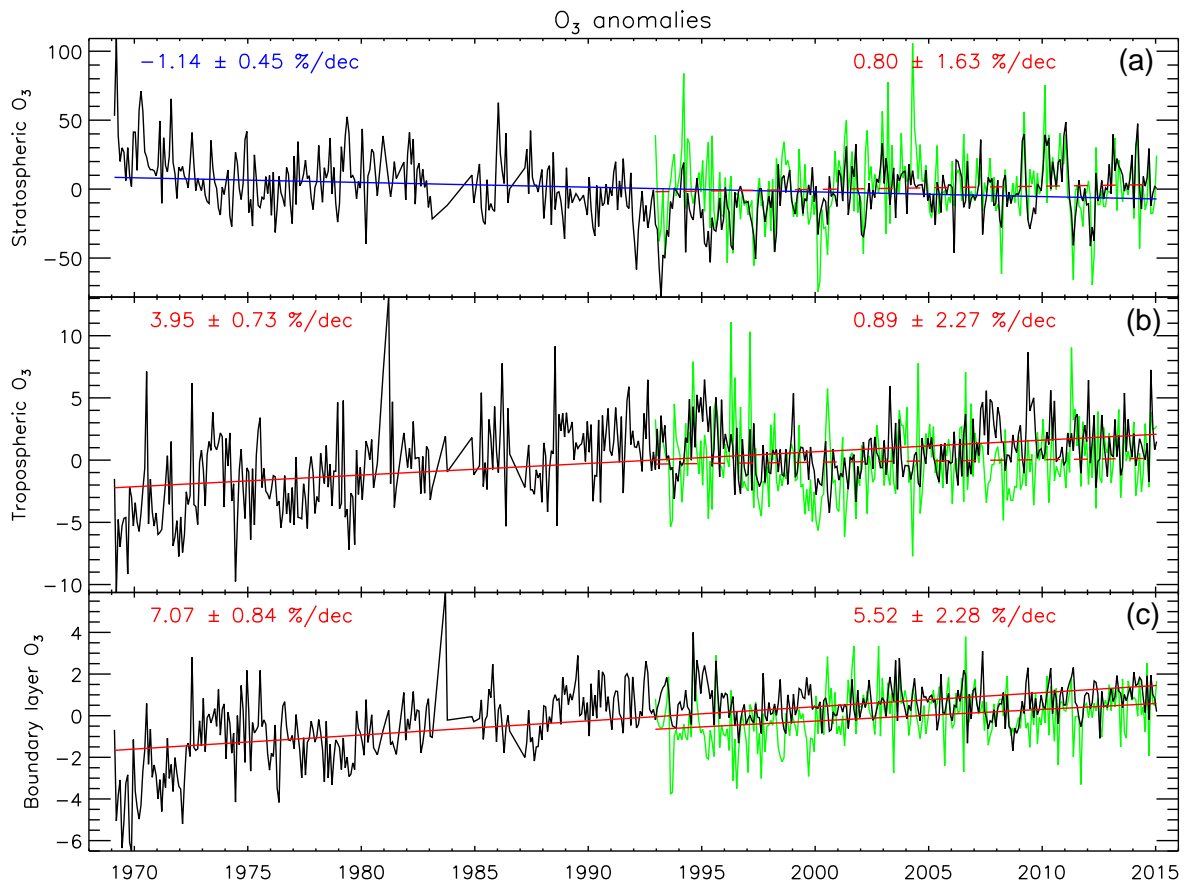

Figure 10. Monthly anomalies of integrated ozone amounts in DU above Uccle (black) and De Bilt (green) for different parts in the atmosphere: (a) stratosphere ( $h>$ tropopause height), (b) free troposphere ( $3 \mathrm{~km}<h<$ tropopause height), and (c) boundary layer ( $0-3 \mathrm{~km})$. The monthly anomalies were calculated for each station by subtracting from every monthly mean the long-term monthly mean over the period 1998-2008. The linear regression lines are also drawn, and their slopes are used to calculate the trends (in \% decade ${ }^{-1}$; left for Uccle, right for De Bilt), together with their $2 \sigma$ uncertainty estimates. Red lines are used for positive trends, blue lines for negative trends. A full line denotes a statistically significant trend. The statistical significance of the trends is investigated by Spearman's test.

troduce a large time dependency with respect to one another and therefore seem to have been consistently applied through the entire BM dataset.

The pump (or box) temperature measurement changed over the BM time period and we found a quality change of the styrofoam boxes and pumps in 1989. Those corrections (see Appendix A), in combination with the corrections for the temperature and pressure dependency of the pump efficiency (see the red curve in Fig. 11), therefore give significant trend differences with the correction algorithms described so far: the ozone trend estimates are reduced at all altitudes (even by $10 \%$ decade $^{-1}$ in the troposphere) because of the total ozone redistribution throughout the profile, except above the ozone maximum where these corrections have the largest impact and the ozone trends increased. The whole set of PRESTO corrections further downsizes the tropospheric ozone trends significantly (see the blue curve in Fig. 11) due to the socalled negative background current correction for BM sondes preconditioned before October 1981 (which will add tropospheric ozone to the profiles) and due to the correction for the $\mathrm{SO}_{2}$ interference on the ozone soundings at Uccle (stronger in the beginning of the time period because of larger $\mathrm{SO}_{2}$ amounts). The change in the vertical profile of the PRESTO stratospheric ozone trends with respect to the previous sets of corrections can be explained by the altitude correction, which is also applied only in the years before 1990 .

These final trends are shown in Fig. 11 together with their trend uncertainty estimates. In the stratosphere, these trends are fairly constant and consistent with altitude, with values in the interval -4 to $-6 \%$ decade $^{-1}$, and statistically significant at all altitudes (except just above the tropopause). This trend estimate is somewhat at the high end range compared with the ozone trends (ranging from -5 to $+1 \%$ decade $^{-1}$ ) derived from different satellite records, ozonesonde, and Umkehr sites for the period $1979-1997$ and the $35-60^{\circ} \mathrm{N}$ latitude band (see Fig. 4 in Harris et al., 2015). In the troposphere, the ozone trends are significantly positive and range from +3 to $+8 \%$ decade $^{-1}$ at the ozone minimum (UT). If the gradient in the tropospheric vertical trends is real, this might point to an increase of stratospheric intrusions during the 1969-1996 time period.

\subsection{The common ECC time series: 1997-2014}

Now we concentrate on the time period in which both the Uccle and the De Bilt station are using ECC ozonesondes, although produced by a different manufacturer. First, we note from Fig. 12 that the different correction methods used at Uccle only have a minor impact on the calculated trends: 


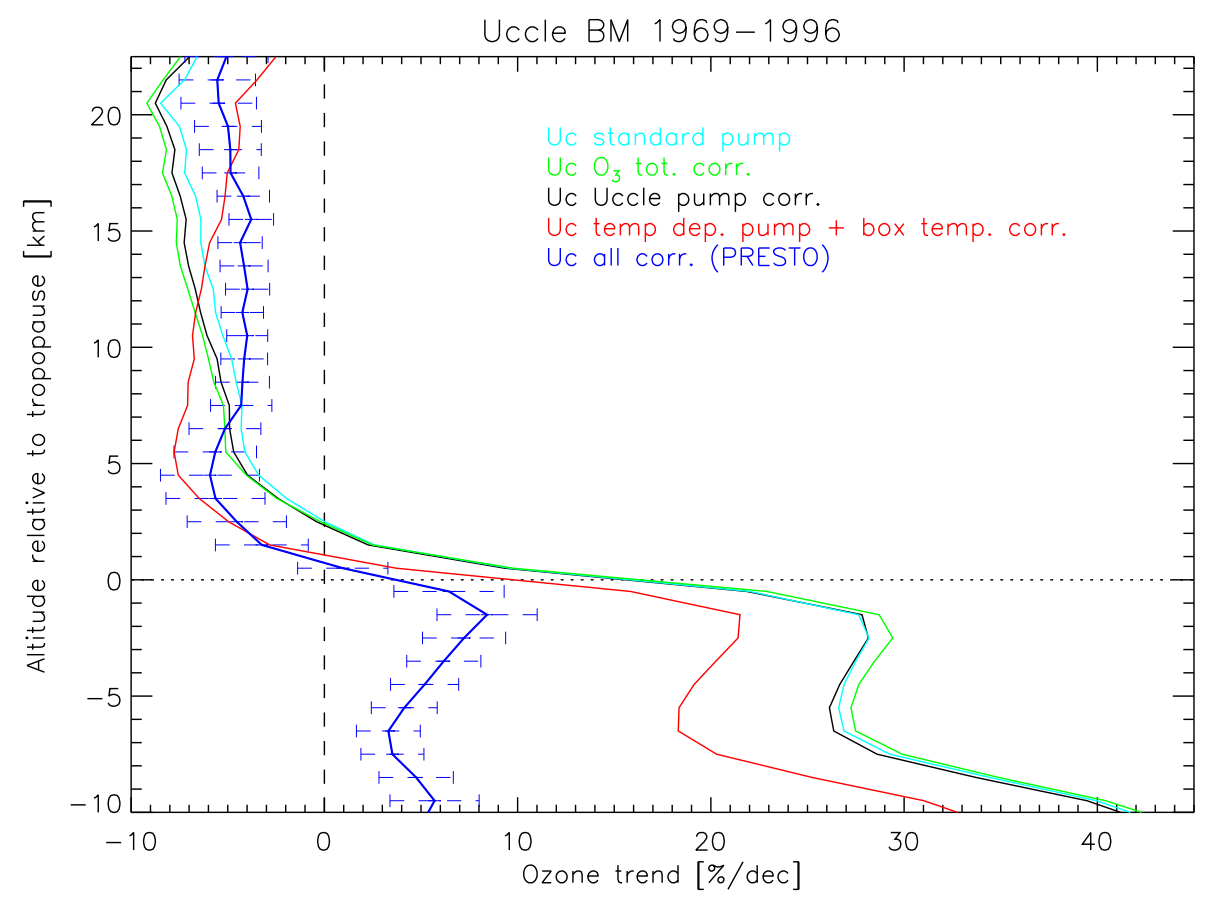

Figure 11. Vertical distribution of the linear relative trends for different correction strategies applied to the Uccle ozonesonde data for BM time period (1969-1996). The trends are estimated for layers of $1 \mathrm{~km}$ height, relative to the tropopause height. The error bars denote the $2 \sigma$ standard errors of the linear regression slope determination after applying all profile corrections and can be considered as a rough estimate of the trend uncertainty.

the trend differences with the standard pump correction are within $\pm 1.5 \%$ decade $^{-1}$, the largest differences occur in the stratosphere. The trends calculated from the O3S-DQA corrections (in grey in Fig. 12) are lowest at all altitudes, maximal by $3 \%$ decade $^{-1}$ in the (upper) stratosphere in comparison with the operational corrections. This can be explained by the use of different pump efficiency corrections factors, the additional O3S-DQA correction for the pump temperature and the PRESTO total ozone normalisation.

The two different correction methods for the De Bilt profiles (in magenta and gold dotted in Fig. 12) have very similar stratospheric trend profiles, in the upper- and lower-stratospheric parts as well. The differences in trends are larger in especially the upper troposphere, even up to $4 \%$ decade $^{-1}$, due to the differences in background current treatment before November 1998. If we consider only the period from 1999, the trend differences between the two corrections at De Bilt nowhere exceed $1 \%$ decade $^{-1}$. For the 19972014 period, at all altitude levels, the O3S-DQA corrections result in higher relative trends for De Bilt, exactly the opposite as for Uccle. As a consequence, only in the lower stratosphere and in the lower part of the free troposphere, the O3SDQA corrections bring the Uccle and De Bilt trend estimates closer to one another (compare the grey and magenta lines in Fig. 12). However, throughout whole the vertical profiles, the O3S-DQA trends for Uccle and De Bilt lie within each error bars and could therefore considered as not significantly different.

The O3S-DQA trends at Uccle and De Bilt are also only in the troposphere significantly different from 0 for the considered time period, and they lie in the range +3 to +7 or $+12 \%$ decade $^{-1}$, which is more or less the same range as the Uccle tropospheric ozone trend values for the 1969-1996 time period. In the stratosphere, the PRESTO correction at Uccle (in blue) leads to significant positive trends from about 5 to $15 \mathrm{~km}$ above the tropopause (error bars are not shown here) and hence also at the altitudes of the ozone maximum. The finding that the applied correction method determines whether the ozone trend is significantly positive or not is important in present-day ozone research. Indeed, the beginning of the period 1997-2014 coincides with the midlatitude stratospheric peak values of the equivalent effective stratospheric chlorine (EESC) abundance (see e.g. Fig. 1-22 in WMO, 2014). The EESC is a sum of chlorine and bromine derived from ODS tropospheric abundances weighted to reflect their potential influence on ozone. Because the EESC had already returned $38-41 \%$ from its peak value by the end of 2012 (WMO, 2014), a major issue in current ozone research is whether the onset of ozone recovery can be detected. Our study demonstrates that, at least for measurements with ozonesondes, caution is needed before qualifying a (statistically) significant ozone increase as the onset of ozone recovery. Compared to the satellite upper-stratospheric 


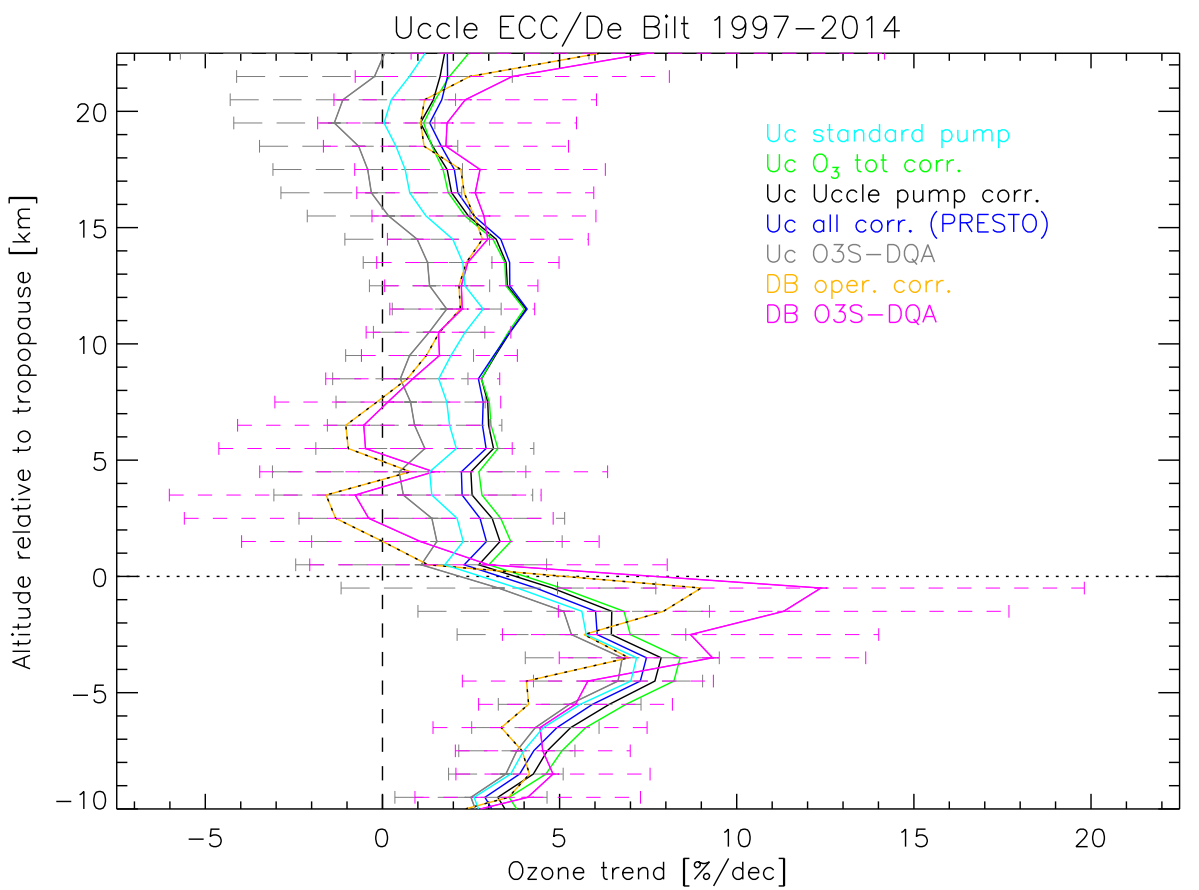

Figure 12. Vertical distribution of the linear relative trends for different correction strategies applied to the Uccle and De Bilt ozone data for the 1997-2014 time period, in which ECC sondes were used at both stations. Trends and error bars are calculated as in Fig. 11.

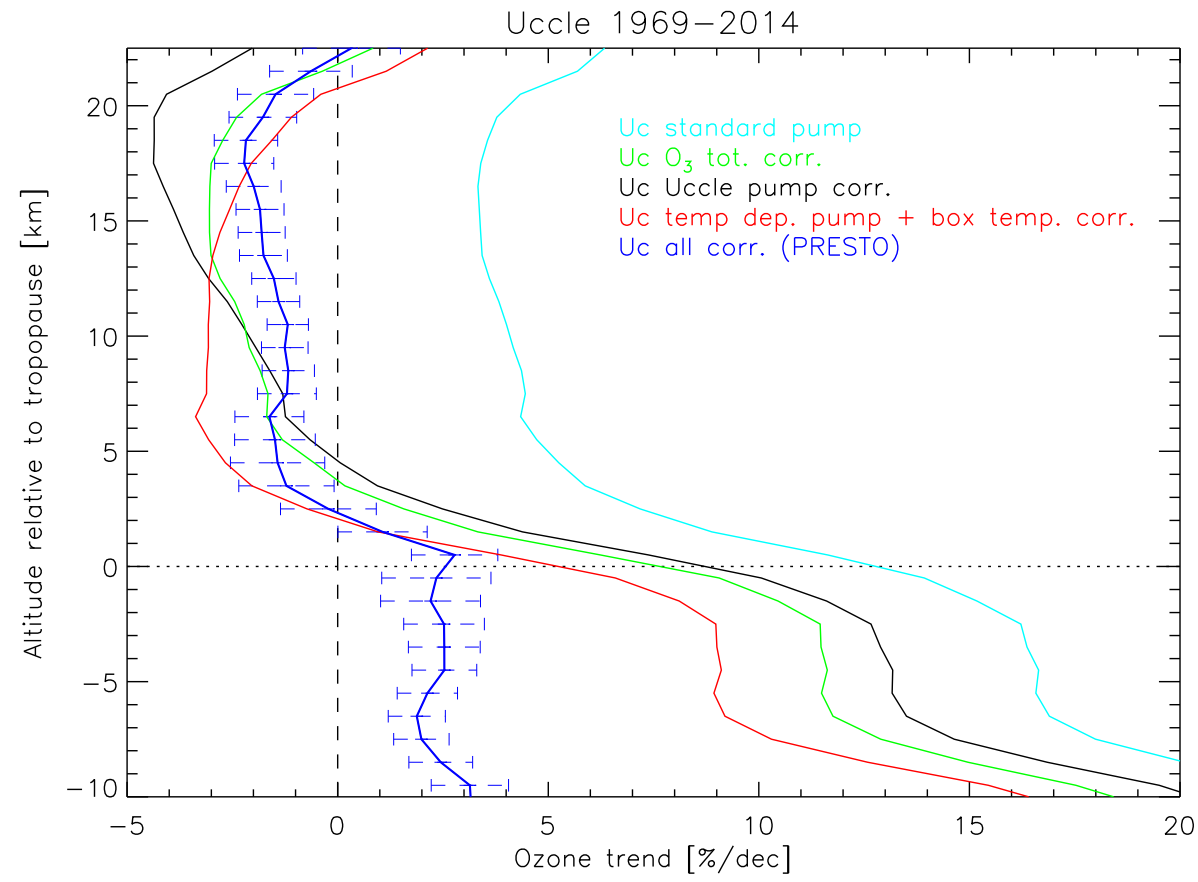

Figure 13. Vertical distribution of the linear relative trends for different correction strategies applied to the Uccle ozone data for the entire time record 1969-2014. Trends and error bars are calculated as in Fig. 11.

ozone trends for the $35-60^{\circ} \mathrm{N}$ latitude band and the period 1998-2012 (Fig. 6 in Harris et al., 2015), the trends for the Uccle and De Bilt stations are also more positive.

\subsection{The entire Uccle time series: 1969-2014}

Because the entire Uccle ozonesonde dataset spans such a long time period, we want to end this section with the de- 
scription of the trends calculated for this $45+$-year time period. In the beginning of this period, all PRESTO algorithms were in use and therefore have a large impact on a trend estimation based on simple linear regression. As a matter of fact, the impact of the different parts of the PRESTO corrections on the trend values, shown in Fig. 13, is very similar as for the BM period only (see Fig. 11) and will therefore not be discussed again. The only notable exception is the large difference between the trends estimated from the profiles corrected only by the standard pump efficiency profiles (cyan curve) and corrected by simple linear total ozone normalisation (in green): the total ozone normalisation is responsible for a relative trend decrease by $6-7 \%$ decade $^{-1}$ in the stratosphere, thereby inducing negative trends in the bulk of the stratosphere, and by around $5 \%$ decade $^{-1}$ in the troposphere. Since this total ozone normalisation corrects for the lacking total ozone response equivalent by the BM sondes at the begin of the period, while the ECC ozonesondes have a nearly full total ozone response equivalent, it is clear that the ozone concentration trends will be smaller after this correction.

The final trends, obtained after executing the whole set of PRESTO post-processing algorithms, are also shown in blue in Fig. 13, together with their trend uncertainty estimates. These resulting trends are even more fairly constant and consistent over the two different atmospheric layers considered here in comparison to the time period 1969-1996: the ozone concentrations increased at a rate of $2-3 \%$ decade $^{-1}$ throughout all the troposphere, and they decreased at a rate of $1-2 \%$ decade $^{-1}$ throughout the stratosphere from 1969 to 2014. Taking the calculated uncertainties into account, these trends are significant at almost all altitude levels. So, although some corrections applied in the PRESTO chain are based on extrapolations for the beginning of the record, it is reassuring that the vertical trend profile only shows a minor dependency on the altitude level within either the stratosphere or the troposphere. The trend estimates have the same sign as in the 1969-1996 time period but are more modest. This is a consequence of the positive ozone trends for the 1997-2014 time period. When considering the entire time period, the tropospheric ozone trends are also smaller than for the two considered subperiods.

\section{Conclusions}

For the nearby stations of Uccle and De Bilt, we calculated average profiles and vertical trend estimates from both the operational and internationally agreed O3S-DQA corrections. Because typical horizontal ozone correlation lengths are generally much longer than the distance between both stations, except in the boundary layer, and because the time separation between the launches at those stations is at most 1 day, the comparisons of the average profiles and trends should enable us to investigate the impact of the correction strategies on the ozone profiles and resulting trends.
In Uccle, where the time series is built up with both BM and ECC ozonesondes, the main feature of the operational PRESTO correction is the combination of a pressure and temperature-dependent pump efficiency correction with the total ozone normalisation. For the BM 1969-1996 time period, the operational corrections result in a relative ozone increase between 20 and $30 \%$ in the average profile with respect to the standard pump efficiency corrections due to the typical BM response being only equivalent to about $80 \%$ of the actual ozone amount. For ECC ozonesondes (19972014), the different correction strategies produce average profiles within $\pm 2 \%$ of this reference. In particular, the O3SDQA correction for ECC ozonesondes adds about $2 \%$ ozone at the tropospheric levels compared to the operational correction, whereas above the ozone maximum the reverse is true, but now with an amount around $1 \%$. For the De Bilt time series (1993-2014), the O3S-DQA average profile has smaller ozone amounts at all altitude levels. Here, the largest relative differences are obtained in the UTLS (about $15 \%$ ) in the period before November 1998, when different background current subtractions have been applied for both corrections.

When comparing the average profiles of Uccle and De Bilt, we conclude that, independently of the (operational/O3S-DQA) correction algorithms applied, higher tropospheric ozone concentrations are measured at Uccle than at De Bilt, which might be ascribed to both instrumental (overestimation of the tropospheric ozone readings by Uccle BM sondes and higher background currents subtracted at De Bilt for the ECC sondes) and natural (more polluted area at Uccle) origins. The highest absolute differences are found in the upper troposphere (more than $20 \%$ for the Uccle BM period 1993-1996 and almost $10 \%$ for the ECC period 1997-2014, in both cases with respect to the De Bilt O3S-DQA corrections), where the ozone concentrations are lowest and the relative uncertainty of the background current dominates the overall ozone measurement relative uncertainty. In the lower-stratospheric layers, the relative differences between the ozone amounts in the average profiles at Uccle and De Bilt do not exceed $\pm 5 \%$, both for the Uccle BM period (sign depending on the correction method applied) and the ECC period (higher ozone amounts are present in De Bilt). Above the ozone maximum, the Uccle-De Bilt relative ozone differences fall in the same $\pm 5 \%$ range for the Uccle $\mathrm{BM}$ period, but increase with height for the ECC period and can amount to up to $10 \%$ at burst altitudes, independently of the used correction method and the radiosonde type used. The reason for these larger discrepancies is not completely clear to us but the higher ascent rates at Uccle certainly strengthen the observed tendency, and geophysical differences between both sites cannot be completely ruled out either. As a matter of fact, the average vertical temperature distributions show differences up to $2 \%$ above Uccle and De Bilt. For the assessment of the O3S-DQA corrections for ECC ozonesondes at both sites, we can conclude that those effectively reduce the relative 
differences between Uccle and De Bilt only in the lower stratosphere (below the ozone maximum), compared to the differences between the operational corrections in use at both sites.

Despite their large impact on the average ozone profiles, the different (meaningful) correction strategies do not change the ozone trends significantly, usually only within their statistical uncertainty due to atmospheric noise. For the entire Uccle time period 1969-2014, the operational corrections result in a fairly constant and consistent trend over the troposphere $\left(+2\right.$ to $+3 \%$ decade $\left.^{-1}\right)$ and stratosphere $(-1$ to $-2 \%$ decade $\left.^{-1}\right)$. These trend estimates are more moderate than the ranges found for the Uccle BM period 1969-1996, which are +3 to +8 and -4 to $-6 \%$ decade $^{-1}$ for the troposphere and stratosphere, respectively, but are all statistically significant. The fact that those trend estimates have such a narrow range in either the stratosphere or the troposphere gives us confidence in some additional PRESTO corrections that are based on extrapolations for the beginning of the record. Finally, for the period 1997-2014, the trends are significantly positive at both stations in the troposphere, with ranges from +3 to $+8 \%$ decade $^{-1}$, and not significantly different from each other at both stations. In the stratosphere, the sign of the ozone trend depends on the station and on the correction method applied, and therefore caution is needed before qualifying a (statistically) significant ozone increase (e.g. between 15 and $25 \mathrm{~km}$ at Uccle for the PRESTO corrected profiles) as the onset of ozone recovery. The Uccle trends calculated from the O3S-DQA corrections are lower at all altitudes, maximum by $3 \%$ decade $^{-1}$ in the (upper) stratosphere, in comparison with the operational correction trends. For De Bilt, the opposite is true, with the largest differences, by about the same amount, in the upper troposphere. Therefore, only in the lower stratosphere and in the lower part of the free troposphere do the O3S-DQA corrections bring the Uccle and De Bilt trend estimates closer to one another.

\section{Data availability}

The operationally corrected ozone sounding data at Uccle and De Bilt are publicly available at the World Ozone and Ultraviolet Radiation Centre (WOUDC, http://www.woudc. org), operated by Environment Canada, Toronto, Ontario, Canada, under the auspices of the World Meteorological Organization, and at the Network for the Detection of Atmospheric Composition Change (NDACC, http://www.ndacc. org). The O3S-DQA corrected ozone sounding data at both stations can currently be obtained upon request from the authors, but will be made available via the above-mentioned channels in the near future, as part of the international O3SDQA activity. 
Appendix A: Additional minor corrections for BM ozonesondes in PRESTO

Here, we give an overview of some additional, minor corrections that are included for BM sondes in the Uccle PRESTO correction method. For the BM sondes, no correction for the background current is made $\left(I_{\mathrm{B}}=0\right)$. However, before October 1981, the ozone concentrations imposed to the sensor during the preconditioning phase in the laboratory were much lower than recommended (WMO, 1987), causing too low ozone concentrations in the lower-tropospheric ascent profiles, as found by comparing the ascent to descent ratios of ozone profiles before and after that date (De Backer, 1994). Therefore, a pressure-dependent amount of ozone partial pressure is added to the ascent profiles from ground to $70 \mathrm{hPa}$, as proposed by De Backer (1999), which can be interpreted as a correction for "a negative BGC caused by impurities in the sensor".

The introduction of Vaisala radiosondes in 1990 allowed the measurement of the temperature in the styrofoam box containing the ozone sensor pump ("box temperature"). Since December 1998, the pump temperature $T_{\mathrm{P}}$ is measured with a thermistor in a hole in the pump. For the ECC sondes, this measured value (either box or pump temperature) is used in Eq. (2). For the BM sondes launched after 1990, we use the measured box temperature as an approximation of $T_{\mathrm{P}}$ instead of a recommended fixed value of $300 \mathrm{~K}$ (WMO, 1987), which is known to produce an overestimation of the ozone partial pressure of about $8 \%$ near the burst altitude. From May 1989 to December 1989, the mean box temperature as derived from the soundings during 1990 and 1991 is used. As the insulating capacity of the styrofoam boxes used before 28 April 1989 was higher, a modified average box temperature profile is used for this period, with a slower temperature decrease adjusted to reach the measured $7^{\circ} \mathrm{C}$ at $10 \mathrm{hPa}$ (instead of $3{ }^{\circ} \mathrm{C}$ thereafter).

With the replacement of the VIZ radiosondes by Vaisala radiosondes in 1990, the accuracy of the pressure measurements increased substantially, which has an impact on the (BM) ozone profile measurements. At Uccle, between 1985 and 1989, more than 450 soundings were used to calculate the differences between the altitudes from the VIZ radiosondes and the altitudes deduced from the tracking of the balloon train with a primary wind-finding radar (De Muer and De Backer, 1992). They showed that a systematic bias of up to $1.5 \mathrm{~km}$ was present near the top of the soundings, caused by the slow response time of the VIZ pressure sensor. Furthermore, the differences seemed to have changed during the campaign period, probably due to an additional calibration error in the period 1985-1988. Consequently, different altitude corrections have been made for these different periods; see De Backer (1999). For the period before 1985, when no radar information is available, the more conservative altitude correction of the period 1988-1989 is applied. Although smaller differences between the radar and Vaisala al- titudes were observed during a small campaign in the period September-December 1989, no altitude correction is made for this type of sonde.

The electrochemical sensors of both BM and ECC ozonesondes are also sensitive to other atmospheric trace gases, such as $\mathrm{SO}_{2}$. The decrease in the ozone readings of $\mathrm{BM}$ sondes is proportional to the $\mathrm{SO}_{2}$ concentration with a proportionality factor of 1 , within the limits of uncertainty (De Backer, 1999, and references therein). However, the total ozone measurements with a Dobson spectrophotometer, used for the total ozone normalisation of the ozone profile when available (before 2009), also suffer from interference with $\mathrm{SO}_{2}$ (De Muer and De Backer, 1993). Since Uccle is located near the large urban area of Brussels, it has been affected by $\mathrm{SO}_{2}$ contamination in the 1970s (the beginning of the time series), but the $\mathrm{SO}_{2}$ levels in the lower-troposphere decreased rapidly in the 1970 s and to a lesser extent in the 1980s. Therefore, without a correction for the $\mathrm{SO}_{2}$ interference, a fictitious (Dobson) total ozone trend has been induced (De Muer and De Backer, 1993) and the lower-tropospheric ozone trends calculated from the BM sondes would be overestimated. Therefore, for Uccle, corrections for the $\mathrm{SO}_{2}$ interference on the BM ozone soundings (and on the Dobson spectrophotometer) are applied (De Backer, 1994, 1999), making use of the in situ measurements of the $\mathrm{SO}_{2}$ density near the ground in the urban area of Brussels (and even at Uccle itself). Since the Z-ECC sondes were not used in Uccle before 1996, when the $\mathrm{SO}_{2}$ concentrations in Brussels had already stabilised at low values, the impact of these concentrations on the ozone soundings is negligible and no correction for $\mathrm{SO}_{2}$ needs to be applied to the ozone profiles obtained with this type of sensor. 
Acknowledgements. Both R. Van Malderen and the ozone sounding program in Uccle are funded by the Solar-Terrestrial Centre of Excellence (STCE), a research collaboration established by the Belgian Federal Government through the action plan for reinforcement of the federal scientific institutes. We acknowledge the operators at Uccle and De Bilt that are responsible for the ozone soundings for their dedication throughout the years. We are also grateful to the reviewers for their constructive feedback, which improved the paper substantially.

Edited by: M. Weber

Reviewed by: two anonymous referees

\section{References}

2008/50/EC: Directive 2008/50/EC of the European Parliament and of the Council of 21 May 2008 on ambient air quality and cleaner air for Europe, Official Journal of the European Union, 2008.

Brewer, A. W. and Milford, J. R.: The Oxford-Kew Ozone Sonde, P. Roy. Soc. Lond. A Mat., 256, 470-495, doi:10.1098/rspa.1960.0120, 1960.

Cooper, O. R., Parrish, D. D., Ziemke, J., Balashov, N. V., Cupeiro, M., Galbally, I. E., Gilge, S., Horowitz, L., Jensen, N. R., Lamarque, J.-F., Naik, V., Oltmans, S. J., Schwab, J., Shindell, D. T., Thompson, A. M., Thouret, V., Wang, Y., and Zbinden, R. M.: Global distribution and trends of tropospheric ozone: An observation-based review, Elem. Sci. Anth., 2, 000029, doi:10.12952/journal.elementa.000029, 2014.

Davies, J., Tarasick, D. W., McElroy, C. T., Kerr, J. B., Fogal, P. F., and Savastiouk, V.: Evaluation of ECC Ozonesonde Preparation Methods from Laboratory Tests and Field Comparisons during MANTRA, in: Proceedings of the Quadrennial Ozone Symposium Sapporo, Japan, 2000, edited by: Bojkov, R. D. and Kazuo, S., 137-138, 2003.

De Backer, H.: Analysis and interpretation of ozone observations at Uccle (1969-1993), PhD thesis, Vrije Universiteit Brussel, 1994.

De Backer, H.: Homogenisation of ozone vertical profile measurements at Uccle, Royal Meteorological Institute of Belgium, Scientific and Technical Publication no. 7, 1-26, available at: ftp: //ftp.kmi.be/dist/meteo/hugo/publ/1999/o3prof.pdf, 1999.

De Backer, H., Schoubs, E., and Allaart, M.: Comparison of Brewer-Mast and ECC ozone sonde profiles at Uccle and De Bilt, in: Proceedings of the Third European Workshop on Polar Stratospheric Ozone, Schliersee, Germany, 18-22 September 1995, Air Pollution Research Report 56, edited by: Pyle, J., Harris, N., and Amanatidis, G., European Commission, 512-515, 1996.

De Backer, H., De Muer, D., and De Sadelaer, G.: Comparison of ozone profiles obtained with Brewer-Mast and Z-ECC sensors during simultaneous ascents, J. Geophys. Res.-Atmos., 103, 19641-19648, doi:10.1029/98JD01711, 1998a.

De Backer, H., De Muer, D., Schoubs, E., and Allaart, M.: A new pump correction profile for Brewer-Mast ozonesondes, in: Proceedings of the 18th Quadrennial Ozone Symposium, l'Aquila, Italy, 12-21 September 1996, edited by: Bojkov, R. and Visconti, G., 891-894, 1998b.

De Muer, D. and De Backer, H.: The discrepancy between stratospheric ozone profiles from balloon soundings and from other techniques: a possible explanation, in: Proceedings of the Qua- drennial Ozone Symposium 1992, Charlottesville, Virginia, USA, 4-13 June 1992, NASA Conf. Publ. 3266, 815-818, 1992.

De Muer, D. and De Backer, H.: Influence of sulfur dioxide trends on Dobson measurements and electrochemical ozone surroundings, Proc. SPIE, 2047, 18-26, doi:10.1117/12.163471, 1993.

Deshler, T., Mercer, J. L., Smit, H. G. J., Stubi, R., Levrat, G., Johnson, B. J., Oltmans, S. J., Kivi, R., Thompson, A. M., Witte, J., Davies, J., Schmidlin, F. J., Brothers, G., and Sasaki, T.: Atmospheric comparison of electrochemical cell ozonesondes from different manufacturers, and with different cathode solution strengths: The Balloon Experiment on Standards for Ozonesondes, J. Geophys. Res.-Atmos., 113, D04307, doi:10.1029/2007JD008975, 2008.

Harris, N. R. P., Staehelin, J. S., and Stolarski, R. S.: The New Initiative on Past Changes in the Vertical Distribution of Ozone, SPARC Newsletter, 37, 23-26, 2011.

Harris, N. R. P., Staehelin, J. S., and Stolarski, R. S.: Progress Report on The SI2N Initiative on Past Changes in the Vertical Distribution of Ozone, SPARC Newsletter, 39, 21-24, 2012.

Harris, N. R. P., Hassler, B., Tummon, F., Bodeker, G. E., Hubert, D., Petropavlovskikh, I., Steinbrecht, W., Anderson, J., Bhartia, P. K., Boone, C. D., Bourassa, A., Davis, S. M., Degenstein, D., Delcloo, A., Frith, S. M., Froidevaux, L., Godin-Beekmann, S., Jones, N., Kurylo, M. J., Kyrölä, E., Laine, M., Leblanc, S. T., Lambert, J.-C., Liley, B., Mahieu, E., Maycock, A., de Mazière, M., Parrish, A., Querel, R., Rosenlof, K. H., Roth, C., Sioris, C., Staehelin, J., Stolarski, R. S., Stübi, R., Tamminen, J., Vigouroux, C., Walker, K. A., Wang, H. J., Wild, J., and Zawodny, J. M.: Past changes in the vertical distribution of ozone - Part 3: Analysis and interpretation of trends, Atmos. Chem. Phys., 15, 9965-9982, doi:10.5194/acp-15-9965-2015, 2015.

Inai, Y., Shiotani, M., Fujiwara, M., Hasebe, F., and Vömel, H.: Altitude misestimation caused by the Vaisala RS80 pressure bias and its impact on meteorological profiles, Atmos. Meas. Tech., 8, 4043-4054, doi:10.5194/amt-8-4043-2015, 2015.

IPCC: Climate Change 2013: The Physical Science Basis. Contribution of Working Group I to the Fifth Assessment Report of the Intergovernmental Panel on Climate Change, Cambridge University Press, Cambridge, UK and New York, NY, USA, doi:10.1017/CBO9781107415324, 2013.

Kobayashi, J. and Toyama, Y.: On various methods of measuring the vertical distribution of atmospheric ozone (III) - carbon iodine type chemical ozonesonde, Pap. Meteorol. Geophys., 17, 113$126,1966$.

Komhyr, W. D.: Nonreactive gas sampling pump, Rev. Sci. Inst., 38, 981-983, 1967.

Komhyr, W. D.: Electrochemical concentration cells for gas analysis, Ann. Geophys., 25, 203-210, 1969.

Komhyr, W. D.: Operations Handbook - Ozone measurements to $40 \mathrm{~km}$ altitude with model 4A-ECC ozone sondes, NOAA Techn. Memorandum ERL-ARL-149, Boulder, Colorado, 1986.

Komhyr, W. D. and Harris, T. B.: Note on flow rate measurements made on Mast-Brewer ozone sensor pumps, Mon. Weather Rev., 93, 267-268, doi:10.1175/15200493(1965)093<0267:NOFRMM>2.3.CO;2, 1965.

Komhyr, W. D., Barnes, R. A., Brothers, G. B., Lathrop, J. A., and Opperman, D. P.: Electrochemical concentration cell ozonesonde performance evaluation during STOIC 1989, J. Geophys. Res.Atmos., 100, 9231-9244, doi:10.1029/94JD02175, 1995. 
Lehmann, P.: An estimate of the vertical ozone profile discrepancy between the australian brewer-mast and electrochemical concentration cell ozonesondes, J. Atmos. Ocean. Tech., 22, 1864-1874, doi:10.1175/JTECH1821.1, 2005.

Lemoine, R. and De Backer, H.: Assessment of the Uccle ozone sounding time series quality using SAGEII data, J. Geophys. Res.-Atmos., 106, 14515-14523, doi:10.1029/2001JD900122, 2001.

Liu, G., Tarasick, D. W., Fioletov, V. E., Sioris, C. E., and Rochon, Y. J.: Ozone correlation lengths and measurement uncertainties from analysis of historical ozonesonde data in North America and Europe, J. Geophys. Res.-Atmos., 114, D04112, doi:10.1029/2008JD010576, 2009.

Liu, G., Liu, J., Tarasick, D. W., Fioletov, V. E., Jin, J. J., Moeini, O., Liu, X., Sioris, C. E., and Osman, M.: A global tropospheric ozone climatology from trajectory-mapped ozone soundings, Atmos. Chem. Phys., 13, 10659-10675, doi:10.5194/acp13-10659-2013, 2013.

Logan, J. A., Staehelin, J., Megretskaia, I. A., Cammas, J.-P., Thouret, V., Claude, H., De Backer, H., Steinbacher, M., Scheel, H.-E., Stübi, R., Fröhlich, M., and Derwent, R.: Changes in ozone over Europe: Analysis of ozone measurements from sondes, regular aircraft (MOZAIC) and alpine surface sites, J. Geophys. Res.-Atmos., 117, D09301, doi:10.1029/2011JD016952, 2012.

McPeters, R. D. and Labow, G. J.: Climatology 2011: An MLS and sonde derived ozone climatology for satellite retrieval algorithms, J. Geophys. Res.-Atmos., 117, D10303, doi:10.1029/2011JD017006, 2012.

Newman, P. A., Oman, L. D., Douglass, A. R., Fleming, E. L., Frith, S. M., Hurwitz, M. M., Kawa, S. R., Jackman, C. H., Krotkov, N. A., Nash, E. R., Nielsen, J. E., Pawson, S., Stolarski, R. S., and Velders, G. J. M.: What would have happened to the ozone layer if chlorofluorocarbons (CFCs) had not been regulated?, Atmos. Chem. Phys., 9, 2113-2128, doi:10.5194/acp-9-2113-2009, 2009.

Schnadt Poberaj, C., Staehelin, J., Brunner, D., Thouret, V., De Backer, H., and Stübi, R.: Long-term changes in UT/LS ozone between the late 1970s and the 1990s deduced from the GASP and MOZAIC aircraft programs and from ozonesondes, Atmos. Chem. Phys., 9, 5343-5369, doi:10.5194/acp-9-5343-2009, 2009.

Smit, H. and Kley, D.: Jülich Ozone Sonde Intercomparison Experiment (JOSIE), world Meteorological Organization, Geneva, 1998.

Smit, H. G. J., Straeter, W., Johnson, B. J., Oltmans, S. J., Davies, J., Tarasick, D. W., Hoegger, B., Stubi, R., Schmidlin, F. J., Northam, T., Thompson, A. M., Witte, J. C., Boyd, I., and Posny, F.: Assessment of the performance of ECC-ozonesondes under quasi-flight conditions in the environmental simulation chamber: Insights from the Juelich Ozone Sonde Intercomparison Experiment (JOSIE), J. Geophys. Res.-Atmos., 112, D19306, doi:10.1029/2006JD007308, 2007.

Smit, H. G. J., Oltmans, S., Deshler, T., Tarasick, D., Johnson, B., Schmidlin, F., Stübi, R., and Davies, J.: SI2N/O3S-DQA Activity: Guide Lines for Homogenization of Ozone Sonde Data, version 19 November 2012, available at: http://www-das.uwyo.edu/ deshler/
NDACC_O3Sondes/O3s_DQA/O3S-DQA-Guidelines\% 20Homogenization-V2-19November2012.pdf, 2012.

Smit, H. G. J. and the Panel for the Assessment of Standard Operation Procedures for Ozonesondes (ASOPOS): Quality Assurance and Quality Control for Ozonesonde Measurements in GAW, available at: http://www.wmo.int/pages/prog/arep/gaw/ documents/GAW_201_30_Sept.pdf, 2011.

SPARC-IOC-GAW: Assessment of Trends in the Vertical Distribution of Ozone, world Meteorological Organization, Geneva, 1998.

Staufer, J., Staehelin, J., Stübi, R., Peter, T., Tummon, F., and Thouret, V.: Trajectory matching of ozonesondes and MOZAIC measurements in the UTLS - Part 2: Application to the global ozonesonde network, Atmos. Meas. Tech., 7, 241-266, doi:10.5194/amt-7-241-2014, 2014.

Stauffer, R. M., Morris, G. A., Thompson, A. M., Joseph, E., Coetzee, G. J. R., and Nalli, N. R.: Propagation of radiosonde pressure sensor errors to ozonesonde measurements, Atmos. Meas. Tech., 7, 65-79, doi:10.5194/amt-7-65-2014, 2014.

Steinbrecht, W., Schwarz, R., and Claude, H.: New pump correction for the brewermast ozone sonde: determination from experiment and instrument intercomparisons, J. Atmos. Ocean. Tech., 15, 144-156, doi:10.1175/15200426(1998)015<0144:NPCFTB>2.0.CO;2, 1998.

Steinbrecht, W., Claude, H., Schönenborn, F., Leiterer, U., Dier, H., and Lanzinger, E.: Pressure and temperature differences between vaisala RS80 and RS92 radiosonde systems, J. Atmos. Ocean. Tech., 25, 909-927, doi:10.1175/2007JTECHA999.1, 2008.

Stübi, R., Levrat, G., Hoegger, B., Viatte, P., Staehelin, J., and Schmidlin, F. J.: In-flight comparison of Brewer-Mast and electrochemical concentration cell ozonesondes, J. Geophys. Res.Atmos., 113, D13302, doi:10.1029/2007JD009091, 2008.

Tarasick, D. W., Davies, J., Anlauf, K., Watt, M., Steinbrecht, W., and Claude, H. J.: Laboratory investigations of the response of Brewer-Mast ozonesondes to tropospheric ozone, J. Geophys. Res.-Atmos., 107, 4308, doi:10.1029/2001JD001167, 2002.

Tarasick, D. W., Davies, J., Smit, H. G. J., and Oltmans, S. J.: A re-evaluated Canadian ozonesonde record: measurements of the vertical distribution of ozone over Canada from 1966 to 2013, Atmos. Meas. Tech., 9, 195-214, doi:10.5194/amt-9-195-2016, 2016.

Van Malderen, R., De Backer, H., Delcloo, A., and Allaart, M.: Identifying the Origin of Anomalous High Tropospheric Ozone in the Ozonesonde Data at Uccle by Comparison with Nearby De Bilt, Atmos. Ocean, 53, 102-116, doi:10.1080/07055900.2014.886552, 2014.

Vömel, H. and Diaz, K.: Ozone sonde cell current measurements and implications for observations of near-zero ozone concentrations in the tropical upper troposphere, Atmos. Meas. Tech., 3, 495-505, doi:10.5194/amt-3-495-2010, 2010.

WMO: Measurement of Atmospheric ozone profiles using the Brewer/Mast sonde, in: Global Ozone Research and Monitoring Project, edited by: Claude, H., Hartmansgruber, R., and Köhler, U., Rep. 17, WMO, Geneva, 1987.

WMO: Scientific Assessment of Ozone Depletion: 2014, World Meteorological Organization, Global Ozone Research and Monitoring Project - Report No. 55, Geneva, Switzerland, 416 pp., available at: http://www.wmo.int/pages/prog/arep/gaw/ozone_ 2014/ozone_asst_report.html, 2014. 